\title{
ANALISIS, EVALUASI, DAN MITIGASI RISIKO ASET TEKNOLOGI INFORMASI MENGGUNAKAN FRAMEWORK OCTAVE DAN FMEA (STUDI KASUS: UNIT PENGELOLA TEKNIS TEKNOLOGI INFORMASI DAN KOMUNIKASI UNIVERSITAS XYZ)
}

\author{
Rut Juniati Gagas ${ }^{[1]}$; Ilhamsyah [2]; Ferdy Febryanto[3] \\ Jurusan Sistem Informasi [1][2][3] \\ Fakultas MIPA Universitas Tanjungpura \\ rut.juniati.gagas@student.untan.ac.id[ $\left.{ }^{1}\right]$; ilhamsyah@sisfo.untan.ac.id[ $\left.{ }^{2}\right]$; ferdyf@sisfo.untan.ac.i $\left[^{3}\right]$
}

\begin{tabular}{ll}
\hline INFO ARTIKEL & INTISARI \\
\hline Diajukan : & Unit Pengelola Teknis Teknologi Informasi dan Komunikasi Universitas \\
12 Juli 2021 & XYZ (UPT. TIK XYZ) merupakan pengembang, pengelola, dan perencana \\
Diterima : & TIK XYZ. Dalam meningkatkan pelayanan Tri Dharma Perguruan Tinggi, \\
30 Juli 2021 & XYZ menggunakan layanan Teknologi Informasi (TI) sebagai strateginya. \\
Diterbitkan: & Ini menunjukan bahwa tantangan untuk UPT. TIK XYZ dalam pelaksanaan \\
01 Desember 2021 & tersebut melibatkan banyak aset TI yang harus dikelola, dan \\
Kata Kunci : & memungkinkan muncul berbagai aset kritis yang berisiko. Dari uraian \\
aset kritis, FMEA, ISO/IEC & tersebut menunjukan pentingnya keamanan aset TI dan manajemen risiko \\
27001:2013, OCTAVE, Mitigasi & aset TI sesuai framework dan standar yang membantu mengurangi atau \\
Risiko & menghilangkan dampak dari kegagalan akibat kerentanan yang ada pada \\
& aset yang kritis. Tujuan penelitian ini untuk mengetahui praktik keamanan \\
& yang digunakan, mengidentifikasi, dan menganalisis aset kritis \\
& menggunakan framework OCTAVE, kemudian mengevaluasi dan menilai \\
& dampak untuk mengukur nilai RPN risiko aset kritis menggunakan \\
& framework FMEA. Serta memberi rekomendasi praktik keamanan \\
& menggunakan OCTAVE Katalog Versi 2.0 dan rekomendasi mitigasi risiko \\
& menggunakan ISO/IEC 27001:2013 dan ISO/IEC 27002:2013. Hasilnya \\
& terdapat 10 praktik keamanan yang memiliki jawaban hasil "Tidak" \\
dan/atau "Tidak Jelas". Kemudian terdapat 19 risiko dengan 22 kejadian & ancaman, dimana level very high memiliki 2 risiko dengan nilai RPN \\
sebesar 280, high memiliki 0 risiko, medium memiliki 3 risiko dengan nilai \\
RPN sebesar 100-140, low memiliki 8 risiko dengan nilai RPN sebesar 30- \\
70, dan very low memiliki 9 risiko dengan nilai RPN sebesar 1-18.
\end{tabular}

\section{PENDAHULUAN}

Institusi perguruan tinggi negeri saat ini banyak berusaha menjadi kampus digital dengan memanfaatkan Teknologi Informasi (TI) sebagai pendukung pelaksanaan Tri Darma Perguruan Tinggi. Pelaksanaan tiga poin tersebut tentunya bagi perguruan tinggi saat ini perlu menyediakan layanan TI yang menunjang pelaksanaan dengan beragam pengguna seperti mahasiswa, dosen, staf kampus, dan publik. Salah satunya Universitas XYZ yang merupakan Perguruan Tinggi yang berada di wilayah Kalimantan Barat, sebuah institusi pendidikan formal, XYZ dituntut untuk mengembangkan Teknologi Informasi dan Komunikasi (TIK) yang mampu mendukung strategi Universitas.

TIK XYZ sendiri ditangani oleh Unit Pengelola Teknis TIK XYZ (UPT. TIK XYZ) sebagai pengembang dan perencana TIK XYZ dimana terdapat 7 program utama yang direncanakan dan dilaksanakan dalam kurun waktu 2018-2022 sebagai bagian dari strategi XYZ. Ini memungkinkan muncul berbagai risiko aset $\mathrm{TI}$, tantangan dan tuntutan untuk UPT. TIK XYZ dalam pelaksanaannya.

Dari uraian tersebut terlihat pentingnya mengelola keamanan aset TI yang ada di UPT.TIK $\mathrm{XYZ}$ dengan mengurangi atau menghilangkan dampak dari kegagalan atau risiko akibat kerentanan yang ada pada aset kritis, tentu ini menjadi tugas penting bagi UPT. TIK XYZ untuk memastikan aset TI yang ada sudah tertangani dengan benar. Masalah penting bagi seorang ahli keamanan saat menghadapi tugas untuk memperkenalkan langkah-langkah keamanan dalam bisnis dan organisasinya salah satunya mengidentifikasi dan menilai dampak organisasi dari implementasi rencana keamanannya (Vacca, 2017). Masalah tersebut menunjukan bahwa 
pentingnya kesiapan UPT. TIK XYZ untuk melaksanakan manajemen risiko aset TI yang dapat mengidentifikasi dan menilai dampak dari implementasi keamanan yang dijalankannya, sesuai framework dan standar yang dapat membantu menangani dan memahami permasalahan dari implementasi TI yang ada.

Dalam penelitian ini peneliti tertarik untuk melakukan manajemen risiko aset TI menggunakan framework dan standar yang dapat mengukur pengetahuan praktik keamanan yang digunakan, mengidentifikasi, dan menganalisis aset kritis menggunakan framework Operational Critical Threat, Asset, and Vulnerability Evaluation (OCTAVE), kemudian mengevaluasi dan menilai dampak untuk mengukur nilai RPN risiko aset kritis menggunakan framework Failure Mode Effect Analysis (FMEA) pada UPT. TIK XYZ. Serta memberi rekomendasi praktik keamanan menggunakan OCTAVE Katalog Versi 2.0 dan rekomendasi mitigasi risiko menggunakan ISO/IEC 27001:2013 dan ISO/IEC 27002:2013.

\section{BAHAN DAN METODE}

Berdasarkan latar belakang tersebut hasil akhir penelitian akan melakukan perancangan dan pembuatan rekomendasi pengembangan praktik strategis dan praktik operasional berdasarkan OCTAVE Katalog versi 2.0 dan rekomendasi mitigasi risiko berdasarkan standar ISO/IEC 27001:2013 dan ISO/IEC 27002:2013. Rekomendasi yang dibuat selanjutnya diuji dengan membandingkan rekomendasi dengan penerapan praktik yang dilakukan saat ini oleh pihak UPT. TIK XYZ untuk melihat potensi penerapan rekomendasi yang sudah di buat dan dirancang berdasarkan hasil analisis wawancara, dan perhitungan nilai persenan hasil survei pengetahuan dari beberapa orang terkait pengetahuan mereka tentang praktik keamanan, yang dianalisis dan dievaluasi menggunakan framework OCTAVE. Selain itu berdasarkan evaluasi dan penilaian dampak risiko tersebut digunakan metode FMEA untuk mencari nilai RPN risiko. Berdasarkan hal itu peneliti menggunakan dua pendekatan kualitatif dan kuantitatif.

Untuk mencapai tujuan dalam penelitian ini terdiri dari beberapa tahapan sebagai berikut:

1. Preparation:

Melakukan persiapan untuk memastikan bahwa evaluasi sudah dicakup dengan benar, bahwa Kepala UPT.TIK XYZ mendukung evaluasi ini, dan bahwa setiap orang yang berpartisipasi dalam proses ini memahami perannya.
2. Fase 1 Organizational View: Proses 1 Proses 4

Mengidentifikasi pengetahuan anggota UPT. TIK XYZ dengan wawancara terkait aset yang berisiko, ancaman, kerentanan dan mengisi survei pengetahuan terkait praktik keamanan yang digunakan saat ini di UPT. TIK XYZ sehingga didapat profil ancaman aset TI dan kelemahan praktik keamanan dan profil risiko ancaman aset TI.

3. Fase 2 Technological View: Proses 5 Proses 6

Memeriksa infrastruktur komputasi yang terkait dengan profil ancaman aset kritis dengan mengevaluasi komponen aset TI sehingga hasil akhirnya ditemukan kerentanan komponen aset TI.

4. Fase 3 Risk Analysis: Proses 7 - 8 Dan Identifikasi Risiko

Menganalisis komponen risiko ancaman aset, kerentanan aset, dan mengukur hasil survei praktik keamanan, dan melakukan identifikasi potential cause dan potential effect dari ancaman dan kerentanan serta mencari nilai RPN risiko berdasarkan FMEA.

5. Validasi Potensi Penerapan Rekomendasi Praktik Keamanan Dan Mitigasi Risiko

Membuat rekomendasi mitigasi risiko berdasarkan standar ISO/IEC 27001:2013 dan ISO/IEC 27002:2013. Selain itu juga rekomendasi pengembangan praktik keamanan secara strategis dan operasional berdasarkan standar OCTAVE Katalog Praktik Versi 2.0. Setelah itu dilakukan pengecekan kesesuaian rekomendasi dengan keadaan UPT. TIK XYZ.

\section{HASIL DAN PEMBAHASAN}

Dari tahapan perancangan yang sudah dijelaskan sebelumnya, hasil dan pembahasan setiap tahapan dijelaskan sebagai berikut:

1. Preparation

Persetujuan dari manajemen senior untuk mendukung evaluasi yaitu Dr. Herry Sujaini, ST.MT selaku Kepala UPT.TIK XYZ, setelah itu dilakukan pemilihan tim analisis inti yang membantu peneliti yaitu Muhd. Rahmadi, S.T selaku pengelola Siakad, selanjutnya pengaturan ruang lingkup area operasional yaitu kepala UPT.TIK XYZ: pengelola sumber daya, pengelola sistem dan jaringan, dan pengelola siakad, dengan peserta evaluasi wawancara dan survei yaitu Dr. Herry Sujaini, ST. MT., Muanuddin, S. T., dan Muhd. Rahmadi, S. T.

2. Fase 1: Membangun Profil Ancaman Berbasis Aset (Build Asset-Based Threat Profiles). 
1) Proses 1: Identify Senior Management Knowledge.

Tahap ini dilakukan wawancara langsung dengan kepala UPT. TIK XYZ untuk mengidentifikasi aset dan memilih aset yang paling penting menurut perspektif nya.

\section{2) Proses 2: Identify Operational Area} Management Knowledge

Tahap ini dilakukan wawancara langsung dengan admin database dan staf jaringan UPT. TIK XYZ untuk mengidentifikasi aset dan memilih aset yang paling penting menurut perspektif nya.

3) Proses 3: Identify Staff Knowledge

Tahap ini dilakukan wawancara langsung dengan admin database dan staf jaringan UPT. TIK XYZ untuk memilih aset yang paling penting menurut perspektif nya.

4) Proses 4: Create Threat Profile

Membuat profil ancaman berdasarkan hasil wawancara proses 1 sampai proses 3 dengan menentukan aset yang berdampak buruk besar jika keamanannya dilanggar bisa dilihat tabel berikut:

Tabel 5. Aset Kritis

\begin{tabular}{|c|c|c|}
\hline No & Kategori & Aset \\
\hline 1. & Data / Informasi & Data nilai \\
\hline 2. & Sistem & Siakad \\
\hline 3. & \multirow{3}{*}{ Hardware } & Server Jaringan \\
\hline 4. & & Kabel \\
\hline 5. & & Server database \\
\hline 6. & \multirow{4}{*}{ Orang } & Admin database \\
\hline 7. & & Operator Siakad/admin sistem \\
\hline 8. & & Programmer \\
\hline 9. & & Admin jaringan \\
\hline
\end{tabular}

Sumber: Hasil Penelitian (2021)

Selanjutnya mencatat alasan penetapan aset yang penting untuk dievaluasi dengan mempertimbangkan mengapa aset dianggap penting untuk memenuhi misi UPT.TIK XYZ bisa dilihat pada tabel berikut:

Tabel 6. Informasi Aset Kritis

\begin{tabular}{|c|c|}
\hline \multicolumn{2}{|c|}{ Informasi Aset Kritis } \\
\hline $\begin{array}{l}\text { 1. Aset: Data / } \\
\text { informasi }\end{array}$ & Data Nilai \\
\hline $\begin{array}{l}\text { Alasan } \\
\text { pemilihan } \\
\text { sebagai aset } \\
\text { penting }\end{array}$ & $\begin{array}{l}\text { Data penting terkait layanan akademik } \\
\text { untuk mahasiswa dan dosen. }\end{array}$ \\
\hline $\begin{array}{l}\text { Deskripsi } \\
\text { singkat }\end{array}$ & $\begin{array}{l}\text { Data yang krusial terkait penilaian dosen } \\
\text { kepada mahasiswa sehingga } \\
\text { membutuhkan data dan informasi yang } \\
\text { valid untuk proses perkuliahan. }\end{array}$ \\
\hline $\begin{array}{l}\text { 2. Aset: } \\
\text { Sistem }\end{array}$ & Siakad \\
\hline $\begin{array}{l}\text { Alasan } \\
\text { pemilihan } \\
\text { sebagai aset } \\
\text { penting }\end{array}$ & $\begin{array}{l}\text { Sistem informasi akademik yang terkait } \\
\text { langsung dengan layanan akademik yang } \\
\text { merupakan core pendidikan. }\end{array}$ \\
\hline $\begin{array}{l}\text { Deskripsi } \\
\text { singkat }\end{array}$ & $\begin{array}{l}\text { Siakad memiliki runtutan proses yang } \\
\text { saling memengaruhi untuk layanan }\end{array}$ \\
\hline
\end{tabular}

\begin{tabular}{|c|c|}
\hline & $\begin{array}{l}\text { penerimaan mahasiswa baru, daftar } \\
\text { ulang mahasiswa, jadwal perkuliahan } \\
\text { dan penilaian perkuliahan. }\end{array}$ \\
\hline $\begin{array}{l}\text { 3. Aset: } \\
\text { Hardware }\end{array}$ & Server Jaringan \\
\hline $\begin{array}{l}\text { Alasan } \\
\text { pemilihan } \\
\text { sebagai aset } \\
\text { penting }\end{array}$ & $\begin{array}{l}\text { Server sebagai jalur transmisi data jika } \\
\text { tidak ada koneksi maka sistem akan } \\
\text { gagal. }\end{array}$ \\
\hline $\begin{array}{l}\text { Deskripsi } \\
\text { singkat }\end{array}$ & $\begin{array}{l}\text { Server jaringan merupakan komputer } \\
\text { dan komponen lainnya yang } \\
\text { menggunakan mikro tik router sebagai } \\
\text { server. }\end{array}$ \\
\hline $\begin{array}{l}\text { 4. Aset: } \\
\text { Hardware }\end{array}$ & Kabel \\
\hline $\begin{array}{l}\text { Alasan } \\
\text { pemilihan } \\
\text { sebagai aset } \\
\text { penting }\end{array}$ & $\begin{array}{l}\text { Kabel sebagai base jaringan dan listrik } \\
\text { semua peralatan berhubungan dengan } \\
\text { listrik dan tidak dapat berjalan tanpa } \\
\text { listrik }\end{array}$ \\
\hline $\begin{array}{l}\text { Deskripsi } \\
\text { singkat }\end{array}$ & $\begin{array}{l}\text { Kabel sebagai base jaringan dan listrik } \\
\text { semua peralatan berhubungan dengan } \\
\text { listrik dan tidak dapat berjalan tanpa } \\
\text { listrik }\end{array}$ \\
\hline $\begin{array}{l}\text { 5. Aset: } \\
\text { Hardware }\end{array}$ & Server Database \\
\hline $\begin{array}{l}\text { Alasan } \\
\text { pemilihan } \\
\text { sebagai aset } \\
\text { penting }\end{array}$ & $\begin{array}{l}\text { Sebagai alat agar sistem dapat berjalan } \\
\text { karena terkait dengan data layanan } \\
\text { mahasiswa dan dosen. }\end{array}$ \\
\hline $\begin{array}{l}\text { Deskripsi } \\
\text { singkat }\end{array}$ & $\begin{array}{l}\text { Server database merupakan komputer } \\
\text { server dan perangkat lainnya yang } \\
\text { mengolah dan menyimpan data Siakad. }\end{array}$ \\
\hline 6. Aset: Orang & Admin Database \\
\hline $\begin{array}{l}\text { Alasan } \\
\text { pemilihan } \\
\text { sebagai aset } \\
\text { penting }\end{array}$ & $\begin{array}{l}\text { Orang yang berkaitan langsung dengan } \\
\text { sistem untuk memberikan layanan data } \\
\text { dapat berjalan dengan baik. }\end{array}$ \\
\hline $\begin{array}{l}\text { Deskripsi } \\
\text { singkat }\end{array}$ & $\begin{array}{l}\text { Orang yang mengkondisikan, server } \\
\text { database dapat berjalan dalam keadaan } \\
\text { baik dan koneksi tersedia setiap saat dan } \\
\text { bertanggung jawab menjaga keamanan } \\
\text { data dalam memenuhi kebutuhan } \\
\text { layanan data. }\end{array}$ \\
\hline 7. Aset: Orang & Operator Siakad / Admin sistem \\
\hline $\begin{array}{l}\text { Alasan } \\
\text { pemilihan } \\
\text { sebagai aset } \\
\text { penting }\end{array}$ & $\begin{array}{l}\text { Orang yang terkait langsung dengan } \\
\text { sistem aplikasi Siakad dan dapat } \\
\text { melakukan segala hal terkait dengan } \\
\text { layanan akademik. }\end{array}$ \\
\hline $\begin{array}{l}\text { Deskripsi } \\
\text { singkat }\end{array}$ & $\begin{array}{l}\text { Admin orang yang mengelola aplikasi } \\
\text { dan operator Siakad orang memiliki level } \\
\text { otoritas yang berbeda-beda di fakultas } \\
\text { atau Prodi bisa melakukan input, } \\
\text { mengubah dan menghapus data terkait } \\
\text { layanan akademik seperti penjadwalan, } \\
\text { rencana studi, data nilai dan lain } \\
\text { sebagainya. }\end{array}$ \\
\hline 8. Aset: Orang & Admin Jaringan \\
\hline $\begin{array}{l}\text { Alasan } \\
\text { pemilihan } \\
\text { sebagai aset } \\
\text { penting }\end{array}$ & $\begin{array}{l}\text { Keberhasilan sistem layanan yang } \\
\text { berjalan di atas jaringan internet yang di } \\
\text { kelola admin jaringan sangat } \\
\text { mempengaruhi kecepatan akses sistem } \\
\text { layanan yang diberikan, keberhasilan } \\
\text { internet mendukung sistem yang baik. }\end{array}$ \\
\hline $\begin{array}{l}\text { Deskripsi } \\
\text { singkat }\end{array}$ & $\begin{array}{l}\text { Bertanggung jawab terkait berjalannya } \\
\text { layanan internet yang mempunyai hak } \\
\text { akses penuh dan kontrol atas dirinya } \\
\text { sendiri dalam penanganan masalah } \\
\text { jaringan yang putus dan lainnya. }\end{array}$ \\
\hline 9. Aset: Orang & Programmer \\
\hline $\begin{array}{l}\text { Alasan } \\
\text { pemilihan }\end{array}$ & $\begin{array}{l}\text { Pengembang sistem yang mempengaruhi } \\
\text { performa layanan sistem, keamanan }\end{array}$ \\
\hline
\end{tabular}




\begin{tabular}{|l|l|}
\hline $\begin{array}{l}\text { sebagai aset } \\
\text { penting }\end{array}$ & $\begin{array}{l}\text { sistem, dan masalah penanganan yang } \\
\text { cepat diatasi terkait dengan integritas } \\
\text { programmer yang mengetahui celah } \\
\text { kelemahan sistem dan bisa melakukan } \\
\text { apa saja terhadap sistem. }\end{array}$ \\
\hline $\begin{array}{l}\text { Deskripsi } \\
\text { singkat }\end{array}$ & $\begin{array}{l}\text { Programmer di posisi kan sesuai job desk } \\
\text { masing-masing sistem layanan dan } \\
\text { memiliki tanggung jawab atas performa } \\
\text { produk layanan yang dihasilkan untuk } \\
\text { memenuhi kebutuhan, memperbaiki } \\
\text { kekurangan dari masalah bug, antarmuka } \\
\text { website. }\end{array}$ \\
\hline
\end{tabular}

Sumber: Hasil Penelitian (2021)

Kemudian, meninjau persyaratan keamanan untuk setiap aset penting dan area perhatian untuk aset tersebut yang sudah diidentifikasi bisa dilihat pada tabel berikut:

Tabel 7. Persyaratan Keamanan

\begin{tabular}{|c|c|c|c|}
\hline $\begin{array}{c}\text { Aset } \\
\text { Kritis }\end{array}$ & $\begin{array}{c}\text { Jenis } \\
\text { Persyaratan } \\
\text { Keamanan }\end{array}$ & $\begin{array}{l}\text { Pr } \\
\text { io } \\
\text { rit } \\
\text { as }\end{array}$ & Kebutuhan \\
\hline \multirow[t]{3}{*}{$\begin{array}{l}\text { Data } \\
\text { Nilai }\end{array}$} & $\begin{array}{c}\text { Kerahasiaan } \\
\text { (Confidentiality) }\end{array}$ & & $\begin{array}{l}\text { Akses hanya yang } \\
\text { berwenang } \\
\text { berdasarkan otorisasi } \\
\text { nya. }\end{array}$ \\
\hline & $\begin{array}{l}\text { Integritas } \\
\text { (Integrity) }\end{array}$ & $\mathbf{X}$ & $\begin{array}{l}\text { Data akurat konsisten } \\
\text { tidak berubah tanpa } \\
\text { izin dari yang berhak } \\
\text { memberi nilai. }\end{array}$ \\
\hline & $\begin{array}{l}\text { Ketersediaan } \\
\text { (Availability) }\end{array}$ & & $\begin{array}{l}\text { Dapat diakses cepat, } \\
\text { tepat, dan tersedia } \\
24 / 7 .\end{array}$ \\
\hline \multirow[t]{3}{*}{ Siakad } & $\begin{array}{c}\text { Kerahasiaan } \\
\text { (Confidentiality) }\end{array}$ & & $\begin{array}{l}\text { Akses hanya yang } \\
\text { berwenang } \\
\text { berdasarkan otoritas } \\
\text { nya. }\end{array}$ \\
\hline & $\begin{array}{l}\text { Integritas } \\
\text { (Integrity) }\end{array}$ & & $\begin{array}{l}\text { Data akurat konsisten } \\
\text { tidak berubah tanpa } \\
\text { izin. }\end{array}$ \\
\hline & $\begin{array}{l}\text { Ketersediaan } \\
\text { (Availability) }\end{array}$ & $\mathbf{X}$ & $\begin{array}{ll}\text { Dapat diakses cepat, } \\
\text { tepat dan tersedia } \\
24 / 7 .\end{array}$ \\
\hline \multirow[t]{3}{*}{$\begin{array}{c}\text { Server } \\
\text { Jaringa } \\
\mathrm{n}\end{array}$} & $\begin{array}{c}\text { Kerahasiaan } \\
\text { (Confidentiality) }\end{array}$ & & $\begin{array}{l}\text { Data server hanya } \\
\text { diketahui orang yang } \\
\text { berwenang }\end{array}$ \\
\hline & $\begin{array}{l}\text { Integritas } \\
\text { (Integrity) }\end{array}$ & & $\begin{array}{l}\text { Perangkat lunak asli } \\
\text { dan berbayar. }\end{array}$ \\
\hline & $\begin{array}{l}\text { Ketersediaan } \\
\text { (Availability) }\end{array}$ & $\mathbf{X}$ & $\begin{array}{l}\text { Dapat diakses cepat, } \\
\text { tepat dan tersedia } 24 / 7\end{array}$ \\
\hline \multirow[t]{3}{*}{ Kabel } & $\begin{array}{c}\text { Kerahasiaan } \\
\text { (Confidentiality) }\end{array}$ & & $\begin{array}{l}\text { Kabel tidak ada } \\
\text { kerahasiaan }\end{array}$ \\
\hline & $\begin{array}{l}\text { Integritas } \\
\text { (Integrity) }\end{array}$ & & $\begin{array}{ll}\text { Kabel } & \text { original } \\
\text { mengikuti } & \text { standar } \\
\text { jaringan. } & \\
\end{array}$ \\
\hline & $\begin{array}{l}\text { Ketersediaan } \\
\text { (Availability) }\end{array}$ & $\mathbf{X}$ & $\begin{array}{lr}\text { Stok kabel cadangan } \\
\text { tersedia 10\% } \\
\text { dibutuhkan } \\
\text { Kabel } \\
\begin{array}{ll} \\
\text { tersambung } \\
\text { aman }\end{array} \\
\end{array}$ \\
\hline \multirow{3}{*}{$\begin{array}{l}\text { Server } \\
\text { Databa } \\
\text { se }\end{array}$} & $\begin{array}{c}\text { Kerahasiaan } \\
\text { (Confidentiality) }\end{array}$ & & $\begin{array}{l}\text { Akses tersedia untuk } \\
\text { yang berwenang. }\end{array}$ \\
\hline & $\begin{array}{l}\text { Integritas } \\
\text { (Integrity) }\end{array}$ & & $\begin{array}{l}\text { Kondisi perangkat baik } \\
\text { dan memiliki speck } \\
\text { yang optimal. }\end{array}$ \\
\hline & $\begin{array}{l}\text { Ketersediaan } \\
\text { (Availability) }\end{array}$ & $\mathbf{X}$ & $\begin{array}{l}\text { Performa akses data } \\
\text { cepat dan dapat }\end{array}$ \\
\hline
\end{tabular}

\begin{tabular}{|c|c|c|c|}
\hline & & & diakses 24/7. \\
\hline \multirow[t]{3}{*}{$\begin{array}{l}\text { Admin } \\
\text { Databa } \\
\text { se }\end{array}$} & $\begin{array}{c}\text { Kerahasiaan } \\
\text { (Confidentiality) }\end{array}$ & & $\begin{array}{l}\text { Menjaga data rahasia } \\
\text { dengan } \\
\text { mendistribusikan data } \\
\text { ke akses yang } \\
\text { berwenang. }\end{array}$ \\
\hline & $\begin{array}{l}\text { Integritas } \\
\text { (Integrity) }\end{array}$ & $\mathbf{X}$ & $\begin{array}{lr}\text { Berlaku } & \text { jujur } \\
\text { bertanggung } & \text { jawab, } \\
\text { dan } & \text { memiliki } \\
\text { kemampuan. } & \\
\end{array}$ \\
\hline & $\begin{array}{l}\text { Ketersediaan } \\
\text { (Availability) }\end{array}$ & & $\begin{array}{l}\text { Dapat berkerja ketika } \\
\text { dibutuhkan. }\end{array}$ \\
\hline \multirow{3}{*}{$\begin{array}{l}\text { Operat } \\
\text { or } \\
\text { Siakad } \\
\text { Admin } \\
\text { Sistem }\end{array}$} & $\begin{array}{c}\text { Kerahasiaan } \\
\text { (Confidentiality) }\end{array}$ & & $\begin{array}{l}\text { Mengakses hanya } \\
\text { bagian wewenang hak } \\
\text { akses yang dimiliki. }\end{array}$ \\
\hline & $\begin{array}{l}\text { Integritas } \\
\text { (Integrity) }\end{array}$ & $\mathbf{X}$ & $\begin{array}{l}\text { Berlaku jujur dan } \\
\text { bertanggung jawab } \\
\text { atas validitas data dan } \\
\text { cepat/tanggap dalam } \\
\text { penanganan masalah } \\
\text { sistem. }\end{array}$ \\
\hline & $\begin{array}{l}\text { Ketersediaan } \\
\text { (Availability) }\end{array}$ & & $\begin{array}{l}\text { Dapat berkerja dimana } \\
\text { saja ketika dibutuhkan. }\end{array}$ \\
\hline \multirow[t]{3}{*}{$\begin{array}{l}\text { Progra } \\
\text { m-mer }\end{array}$} & $\begin{array}{c}\text { Kerahasiaan } \\
\text { (Confidentiality) }\end{array}$ & & $\begin{array}{l}\text { Menjaga } \\
\text { data/informasi sistem } \\
\text { yang rahasia. }\end{array}$ \\
\hline & $\begin{array}{l}\text { Integritas } \\
\text { (Integrity) }\end{array}$ & $\mathbf{X}$ & $\begin{array}{lr}\text { Berlaku } & \text { jujur } \\
\text { bertanggung } & \text { jawab, } \\
\text { dan } & \text { memiliki } \\
\text { kemampuan. } & \\
\end{array}$ \\
\hline & $\begin{array}{l}\text { Ketersediaan } \\
\text { (Availability) }\end{array}$ & & $\begin{array}{l}\text { Dapat berkerja dimana } \\
\text { saja ketika dibutuhkan. }\end{array}$ \\
\hline \multirow[t]{3}{*}{$\begin{array}{l}\text { Admin } \\
\text { Jaringa } \\
\mathrm{n}\end{array}$} & $\begin{array}{c}\text { Kerahasiaan } \\
\text { (Confidentiality) }\end{array}$ & & $\begin{array}{l}\text { Menjaga } \\
\text { data/informasi yang } \\
\text { rahasia. }\end{array}$ \\
\hline & $\begin{array}{l}\text { Integritas } \\
\text { (Integrity) }\end{array}$ & $\mathbf{X}$ & $\begin{array}{lr}\begin{array}{lr}\text { Berlaku } & \text { jujur } \\
\text { bertanggung } & \text { jawab, } \\
\text { dan } & \text { memiliki } \\
\text { kemampuan } & \text { terhadap } \\
\text { ketersediaan } & \text { layanan } \\
\text { internet. } & \\
\end{array} \\
\end{array}$ \\
\hline & $\begin{array}{l}\text { Ketersediaan } \\
\text { (Availability) }\end{array}$ & & $\begin{array}{l}\text { Dapat berkerja dimana } \\
\text { saja ketika dibutuhkan. }\end{array}$ \\
\hline
\end{tabular}

Sumber: Hasil Penelitian (2021)

Selanjutnya memetakan area yang menjadi perhatian atau potensi ancaman terhadap aset penting tersebut bisa dilihat pada tabel berikut:

Tabel 8. Area Perhatian Area Perhatian Data Nilai

1. Penyingkapan data akibat akses menggunakan komputer umum yang dipasang aplikasi spy.

2. Data berubah akibat modifikasi oleh operator Siakad.

3. Data hilang atau terhapus akibat salah setting periode atau tahun ajaran pada aplikasi Siakad. Area Perhatian Siakad

1. Akses layanan sistem lambat atau tidak tersedia akibat serangan DDoS, malware, atau kode berbahaya pada sistem.

2. Tampilan halaman utama web berubah akibat serangan deface.

3. Data login di ketahui orang yang tidak berhak dan berwenang.

\section{Area Perhatian Server Jaringan}

1. Data pada server di ketahui orang yang tidak berwenang.

2. Server mati atau rusak akibat masalah ketersediaan listrik yang tidak stabil.

3. Konektivitas jaringan putus akibat pemblokiran koneksi 
ke access point.

4. IP konflik akibat serangan duplikasi alamat IP. Area Perhatian Kabel

1. Kabel putus akibat human error saat beraktivitas tersentuh atau ditarik tidak sengaja.

2. Pemutusan kabel akibat pembangunan yang tanpa izin yang jelas.

\section{Area Perhatian Server Database}

1. Kinerja server tidak optimal atau sistem error akibat speck perangkat yang tidak memenuhi kebutuhan.

2. Server panas atau rusak akibat masalah listrik.

3. Masalah konfigurasi fisik akibat kabel lepas.

$$
\text { Admin Database }
$$

1. Melakukan perubahan data tanpa izin dari yang berwenang.

\section{Operator Siakad/Admin Sistem}

1. Melakukan perubahan data nilai tanpa izin dari yang berwenang.

Programmer

1. Masalah kesadaran keamanan sistem dan penanganan lambat terhadap layanan sistem yang bermasalah.

\section{Admin Jaringan}

1. Masalah kesadaran keamanan jaringan dan penanganan ketersediaan layanan internet yang putus.

Sumber: Hasil Penelitian (2021)

Kemudian memetakan area yang menjadi perhatian ancaman ke profil ancaman, dimana identifikasi profil ancaman berdasarkan kategori human actor using physical access, human actor using network access, system problems dan other problems bisa dilihat pada tabel berikut:

Tabel 9. Properti Ancaman yang Menjadi

Perhatian

\begin{tabular}{|c|c|}
\hline Area Perhatian & Properti Ancaman \\
\hline $\begin{array}{l}\text { 1. Penyingkapan data } \\
\text { akibat akses } \\
\text { menggunakan } \\
\text { komputer umum } \\
\text { yang dipasang } \\
\text { aplikasi spy. }\end{array}$ & $\begin{array}{l}\text { Aset — data nilai } \\
\text { Akses — fisik (akses Siakad } \\
\text { menggunakan komputer umum } \\
\text { yang dipasang aplikasi spy) } \\
\text { Aktor — inside (user yang } \\
\text { memiliki hak akses) } \\
\text { Motif — kebetulan } \\
\text { Hasil — penyingkapan (data } \\
\text { dibobol dan di salah gunakan } \\
\text { orang yang tidak berwenang) }\end{array}$ \\
\hline $\begin{array}{l}\text { 2. Data berubah akibat } \\
\text { modifikasi oleh } \\
\text { operator Siakad. }\end{array}$ & $\begin{array}{l}\text { Aset_- data nilai } \\
\text { Akses — jaringan (mengubah } \\
\text { data langsung ke sistem aplikasi } \\
\text { Siakad) } \\
\text { Aktor _ inside (operator yang } \\
\text { memiliki hak akses) } \\
\text { Motif_disengaja } \\
\text { Hasil__ modifikasi (data } \\
\text { berubah) }\end{array}$ \\
\hline $\begin{array}{l}\text { 3. Data hilang atau } \\
\text { terhapus akibat } \\
\text { salah setting periode } \\
\text { atau tahun ajaran } \\
\text { pada aplikasi Siakad. }\end{array}$ & $\begin{array}{l}\text { Aset_- data nilai } \\
\text { Akses — jaringan (kesalahan } \\
\text { setting periode atau tahun ajaran } \\
\text { pada aplikasi Siakad) } \\
\text { Aktor — inside (operator yang } \\
\text { memiliki hak akses) } \\
\text { Motif — kebetulan } \\
\text { Hasil — gangguan (data hilang } \\
\text { atau terhapus) }\end{array}$ \\
\hline $\begin{array}{l}\text { 4. Akses layanan } \\
\text { sistem lambat atau } \\
\text { tidak tersedia akibat } \\
\text { serangan } \quad \text { DDoS, }\end{array}$ & $\begin{array}{l}\text { Aset — siakad } \\
\text { Akses - jaringan } \\
\text { Aktor — serangan DDoS, } \\
\text { malware atau kode berbahaya }\end{array}$ \\
\hline
\end{tabular}

\begin{tabular}{|c|c|}
\hline $\begin{array}{ll}\text { malware atau } & \text { kode } \\
\text { berbahaya } & \text { pada } \\
\text { sistem. } & \end{array}$ & $\begin{array}{l}\text { (hacker) } \\
\text { Motif - disengaja } \\
\text { Hasil - gangguan (akses sistem } \\
\text { lambat atau tidak tersedia) }\end{array}$ \\
\hline $\begin{array}{l}\text { 5. Tampilan halaman } \\
\text { utama web berubah } \\
\text { akibat serangan } \\
\text { deface. }\end{array}$ & $\begin{array}{l}\text { Aset_-Siakad } \\
\text { Aktor — serangan deface } \\
\text { (hacker) } \\
\text { Hasil_-modifikasi (Tampilan } \\
\text { halaman utama web berubah) }\end{array}$ \\
\hline $\begin{array}{l}\text { 6. Data login di ketahui } \\
\text { orang yang tidak } \\
\text { berhak } \\
\text { berwenang }\end{array}$ & $\begin{array}{l}\text { Aset_-Siakad } \\
\text { Akses — fisik (akses } \\
\text { menggunakan komputer umum } \\
\text { yang dipasang spy atau sharing } \\
\text { email dan password) } \\
\text { Aktor — inside (user yang } \\
\text { memiliki hak akses) } \\
\text { Motif — kebetulan dan disengaja } \\
\text { Hasil _ Penyingkapan (data } \\
\text { login diketahui orang yang tidak } \\
\text { berwenang dan penyalahgunaan } \\
\text { data) dan Modifikasi (perubahan } \\
\text { data LIRS, Login dll) }\end{array}$ \\
\hline $\begin{array}{l}\text { 7. Data pada server } \\
\text { di ketahui } \begin{array}{r}\text { orang } \\
\text { yang }\end{array} \text { tidak } \\
\text { berwenang. }\end{array}$ & $\begin{array}{l}\text { Aset_-server Jaringan (data } \\
\text { server) } \\
\text { Akses - fisik (inside) dan } \\
\text { jaringan (outside) } \\
\text { Aktor — inside (staf yang tidak } \\
\text { berwenang) dan outside (hacker) } \\
\text { Motif — disengaja } \\
\text { Hasil — Modifikasi (perubahan } \\
\text { setting server) dan Gangguan } \\
\text { (server down) }\end{array}$ \\
\hline $\begin{array}{l}\text { 8. Server mati atau } \\
\text { rusak akibat } \\
\text { masalah } \\
\text { ketersediaan } \\
\text { listrik yang tidak } \\
\text { stabil. }\end{array}$ & $\begin{array}{l}\text { Aset — server jaringan } \\
\text { Aktor — masalah ketersediaan } \\
\text { listrik } \\
\text { Hasil — kerugian, kehancuran } \\
\text { (server panas atau rusak) }\end{array}$ \\
\hline 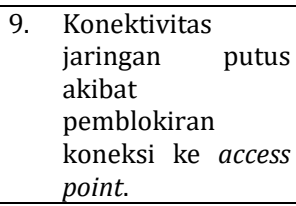 & $\begin{array}{l}\text { Aset — server jaringan } \\
\text { Aktor — serangan pemblokiran } \\
\text { access point (hacker) } \\
\text { Hasil — gangguan (koneksi } \\
\text { internet putus) }\end{array}$ \\
\hline $\begin{array}{l}\text { 10. IP konflik akibat } \\
\text { serangan duplikasi } \\
\text { alamat IP. }\end{array}$ & $\begin{array}{l}\text { Aset - server jaringan } \\
\text { Aktor — serangan duplikasi } \\
\text { alamat IP (hacker) } \\
\text { Hasil — gangguan (sistem crash } \\
\text { atau error) }\end{array}$ \\
\hline $\begin{array}{lr}\text { 11. Kabel putus akibat } \\
\text { human error saat } \\
\text { beraktivitas } \\
\text { tersentuh } \\
\text { ditarik atau } \\
\text { sengaja. }\end{array}$ & $\begin{array}{l}\text { Aset — kabel } \\
\text { Akses — fisik (Kabel) } \\
\text { Aktor — human error saat } \\
\text { beraktivitas tersentuh atau } \\
\text { ditarik (inside dan outside) } \\
\text { Motif — kebetulan } \\
\text { Hasil — gangguan (akses } \\
\text { koneksi internet putus) }\end{array}$ \\
\hline $\begin{array}{l}\text { 12. Pemutusan kabel } \\
\text { akibat } \\
\text { pembangunan } \\
\text { yang tanpa izin } \\
\text { yang jelas. }\end{array}$ & $\begin{array}{l}\text { Aset — kabel } \\
\text { Akses — fisik (Kabel fiber optic) } \\
\text { Aktor — Pemutusan kabel akibat } \\
\text { pembangunan yang tanpa izin } \\
\text { yang jelas. (outside) } \\
\text { Motif — disengaja } \\
\text { Hasil — Gangguan (akses } \\
\text { koneksi internet ke client atau } \\
\text { server terputus) dan Kerugian, } \\
\text { kehancuran (Kerugian secara } \\
\text { finansial, waktu, tenaga dalam } \\
\text { perbaikan infrastruktur yang } \\
\text { hancur) }\end{array}$ \\
\hline 13. Kil & Aset — server database \\
\hline
\end{tabular}




\begin{tabular}{|c|c|c|}
\hline & $\begin{array}{l}\text { tidak optimal atau } \\
\text { sistem error akibat } \\
\text { speck perangkat } \\
\text { yang tidak } \\
\text { memenuhi } \\
\text { kebutuhan. }\end{array}$ & $\begin{array}{l}\text { Aktor — speck perangkat } \\
\text { memory CPU, komputer tidak } \\
\text { memenuhi layanan } \\
\text { Hasil - gangguan (sistem error } \\
\text { data terhapus atau tidak bisa } \\
\text { disimpan) }\end{array}$ \\
\hline & $\begin{array}{l}\text { Server panas atau } \\
\text { rusak akibat } \\
\text { masalah listrik. }\end{array}$ & $\begin{array}{l}\text { Aset — server database } \\
\text { Aktor — listrik tidak stabil } \\
\text { Hasil — kerugian, kehancuran } \\
\text { (server panas atau rusak) }\end{array}$ \\
\hline 15. & $\begin{array}{l}\text { Masalah } \\
\text { konfigurasi fisik } \\
\text { akibat kabel lepas. }\end{array}$ & $\begin{array}{l}\text { Aset — server database } \\
\text { Aktor — masalah konfigurasi } \\
\text { fisik kabel lepas. } \\
\text { Hasil — gangguan (akses } \\
\text { jaringan terputus) }\end{array}$ \\
\hline 16. & $\begin{array}{l}\text { Melakukan } \\
\text { perubahan data } \\
\text { tanpa izin dari } \\
\text { yang berwenang. }\end{array}$ & $\begin{array}{l}\text { Aset — admin database } \\
\text { Akses — fisik (melakukan } \\
\text { perubahan data langsung ke } \\
\text { database Siakad) } \\
\text { Aktor — inside (admin database) } \\
\text { Motif — disengaja } \\
\text { Hasil — modifikasi (data tidak } \\
\text { valid tanpa diketahui sebab atau } \\
\text { jejak) }\end{array}$ \\
\hline 17. & $\begin{array}{lr}\text { Melakukan } & \\
\text { perubahan } & \text { data } \\
\text { nilai tanpa } & \text { izin } \\
\text { dari } & \text { yang } \\
\text { berwenang. } & \end{array}$ & $\begin{array}{l}\text { Aset_operator siakad/admin } \\
\text { sistem } \\
\text { Akses - jaringan (melakukan } \\
\text { perubahan data secara langsung } \\
\text { ke sistem aplikasi Siakad) } \\
\text { Aktor —inside (operator Siakad } \\
\text { / admin sistem yang memiliki } \\
\text { hak akses yang sah) } \\
\text { Motif — disengaja } \\
\text { Hasil - modifikasi (data tidak } \\
\text { valid) }\end{array}$ \\
\hline 18. & $\begin{array}{l}\text { Masalah } \\
\text { kesadaran } \\
\text { keamanan sistem } \\
\text { dan penanganan } \\
\text { lambat terhadap } \\
\text { layanan sistem } \\
\text { yang bermasalah. }\end{array}$ & $\begin{array}{l}\text { Aset - programmer } \\
\text { Aktor — masalah kesadaran } \\
\text { keamanan sistem dan } \\
\text { penanganan lambat terhadap } \\
\text { layanan sistem yang bermasalah. } \\
\text { Hasil — gangguan (layanan } \\
\text { sistem tidak tersedia) }\end{array}$ \\
\hline 19. & $\begin{array}{l}\text { Masalah } \\
\text { kesadaran } \\
\text { keamanan } \\
\text { jaringan dan } \\
\text { penanganan } \\
\text { ketersediaan } \\
\text { layanan internet } \\
\text { yang putus. }\end{array}$ & $\begin{array}{l}\text { Aset_admin jaringan } \\
\text { Aktor — masalah kesadaran } \\
\text { keamanan jaringan dan } \\
\text { penanganan ketersediaan } \\
\text { layanan internet yang putus. } \\
\text { Hasil - gangguan (layanan } \\
\text { internet tidak tersedia) }\end{array}$ \\
\hline
\end{tabular}

Sumber: Hasil Penelitian (2021)

3. Fase 2 technological view: proses 5 - proses 6 .

1) Proses 5: Identifikasi Kelas Utama Komponen (Identifying Key Components).

Proses ini melihat aset dan ancaman penting dari fase 1 kaitannya dengan infrastruktur komputasi memeriksa jalur akses jaringan bisa dilihat pada tabel berikut:

\section{Tabel 10. Key Classes of Components}

\begin{tabular}{|l|l|}
\hline Komponen & \multicolumn{1}{|c|}{ Deskripsi Kelas } \\
\hline Data: & $\begin{array}{l}\text { Data yang penting untuk memberikan layanan } \\
\text { akademik yang merupakan core layanan } \\
\text { Universitas XYZ dalam layanan teknologi } \\
\text { informasi oleh UPT.TIKXYZ. }\end{array}$ \\
\hline Server & $\begin{array}{l}\text { Komputer (host), atau perangkat lain dalam } \\
\text { infrastruktur teknologi informasi UPT. TIK XYZ }\end{array}$ \\
\hline
\end{tabular}

\begin{tabular}{|l|l|}
\hline & $\begin{array}{l}\text { yang menyediakan layanan teknologi informasi } \\
\text { untuk layanan sistem akademik. }\end{array}$ \\
\hline $\begin{array}{l}\text { Perangkat } \\
\text { Jaringan }\end{array}$ & $\begin{array}{l}\text { Perangkat yang penting untuk akses jaringan } \\
\text { layanan teknologi informasi (mis., komponen } \\
\text { nirkabel seperti router dan kabel). }\end{array}$ \\
\hline People & $\begin{array}{l}\text { SDM yang berpengaruh besar terhadap } \\
\text { berjalannya layanan dimana posisinya tidak } \\
\text { dapat digantikan jika dibutuhkan dan dituntut } \\
\text { berintegritas dan profesional (mis., admin } \\
\text { database, operator Siakad/admin sistem, } \\
\text { programmer dan admin jaringan) }\end{array}$ \\
\hline
\end{tabular}

Sumber: Hasil Penelitian (2021)

2) Proses 6: Mengevaluasi Komponen yang dipilih (Evaluate Selected Components).

Mengevaluasi kerentanan aset yang sebelumnya sudah diidentifikasi dengan menggabungkan seluruh data informasi yang diperoleh bisa dilihat tabel berikut:

Tabel 11. Kerentanan Aset

\begin{tabular}{|c|c|}
\hline Aset & Kerentanan \\
\hline \multirow{2}{*}{$\begin{array}{l}\text { Data: } \\
\text { Nilai }\end{array}$} & Kesadaran keamanan yang kurang \\
\hline & Ancaman orang dalam \\
\hline \multirow[t]{3}{*}{ Sistem } & Serangan DDoS, malware atau kode berbahaya \\
\hline & Serangan deface \\
\hline & Kesadaran keamanan yang kurang \\
\hline \multirow[t]{6}{*}{ Server } & Kesadaran keamanan yang kurang \\
\hline & Terlalu panas \\
\hline & Serangan pemblokiran access point \\
\hline & Serangan duplikasi alamat IP \\
\hline & $\begin{array}{l}\text { kerentanan terhadap penyimpanan yang tidak } \\
\text { dilindungi }\end{array}$ \\
\hline & Ancaman orang dalam \\
\hline \multirow[b]{2}{*}{$\begin{array}{c}\text { Perangkat } \\
\text { jaringan }\end{array}$} & Ancaman orang dalam dan luar \\
\hline & $\begin{array}{l}\text { Jalur komunikasi yang tidak terlindungi (tidak } \\
\text { ada kebijakan izin pemutusan kabel dan ganti } \\
\text { rugi yang jelas ke pihak UPT. TIK XYZ) }\end{array}$ \\
\hline \multirow[t]{6}{*}{ Server } & Kesadaran keamanan yang kurang \\
\hline & Terlalu panas \\
\hline & Serangan pemblokiran access point \\
\hline & Serangan duplikasi alamat IP \\
\hline & $\begin{array}{l}\text { kerentanan terhadap penyimpanan yang tidak } \\
\text { dilindungi }\end{array}$ \\
\hline & Ancaman orang dalam \\
\hline \multirow{2}{*}{$\begin{array}{c}\text { Perangkat } \\
\text { jaringan }\end{array}$} & Ancaman orang dalam dan luar \\
\hline & $\begin{array}{l}\text { Jalur komunikasi yang tidak terlindungi (tidak } \\
\text { ada kebijakan izin pemutusan kabel dan ganti } \\
\text { rugi yang jelas ke pihak UPT. TIK XYZ) }\end{array}$ \\
\hline \multirow[t]{2}{*}{ People } & Ancaman orang dalam \\
\hline & $\begin{array}{l}\text { Kesadaran keamanan dan penanganan masalah } \\
\text { lambat. }\end{array}$ \\
\hline
\end{tabular}

4. Fase 3 risk analysis: proses $7-8$ dan identifikasi risiko.

1) Proses 7: Melakukan Analisis Risiko (Conducting the Risk Analysis)

Melakukan analisis komponen risiko ancaman, aset dan kerentanan pada aset secara teknologi dengan memetakan kerentanan, potential cause dan potential effects untuk perhitungan FMEA pada tahap selanjutnya bisa dilihat pada tabel berikut: 
Tabel 12. Potential Cause dan Potential Effects

\begin{tabular}{|c|c|c|c|c|c|c|c|c|c|c|c|}
\hline \multirow{2}{*}{ Kode } & \multirow{2}{*}{ Aset } & \multirow[b]{2}{*}{$\begin{array}{c}\text { Kerentana } \\
\mathbf{n}\end{array}$} & \multirow{2}{*}{ Ancaman } & \multirow[b]{2}{*}{$\begin{array}{l}\text { Potentia } \\
\text { I Cause }\end{array}$} & \multirow[b]{2}{*}{$\begin{array}{c}\text { Poten } \\
\text { tial } \\
\text { Effect } \\
s \\
\end{array}$} & \multirow{3}{*}{ R3.1 } & & & \multirow{3}{*}{$\begin{array}{l}\text { Perubahan } \\
\text { pengaturan } \\
\text { (setting) } \\
\text { server }\end{array}$} & $d$ & \multirow{3}{*}{$\begin{array}{c}\text { Perub } \\
\text { ahan } \\
\text { penga } \\
\text { turan } \\
\text { (setti } \\
\text { ng) } \\
\text { serve } \\
\text { r }\end{array}$} \\
\hline & & & & & & & \multirow{2}{*}{$\begin{array}{l}\text { Hard } \\
\text { ware } \\
\text { : } \\
\text { Serv } \\
\text { er } \\
\text { Jarin } \\
\text { gan }\end{array}$} & \multirow[t]{2}{*}{$\begin{array}{c}\text { Kesadaran } \\
\text { keamanan } \\
\text { yang } \\
\text { kurang. }\end{array}$} & & \multirow{2}{*}{$\begin{array}{l}\text { Data } \\
\text { pada } \\
\text { server di } \\
\text { ketahui } \\
\text { orang } \\
\text { yang } \\
\text { tidak } \\
\text { berwena } \\
\text { ng }\end{array}$} & \\
\hline \multirow[t]{2}{*}{ R1.1 } & \multirow[t]{2}{*}{$\begin{array}{l}\text { Da } \\
\text { ta: } \\
\text { Data } \\
\text { Nilai }\end{array}$} & \multirow[t]{2}{*}{$\begin{array}{l}\text { Kesadaran } \\
\text { keamanan } \\
\text { yang } \\
\text { kurang }\end{array}$} & \multirow{2}{*}{$\begin{array}{c}\text { Data } \\
\text { dibobol } \\
\text { dan di } \\
\text { salah } \\
\text { gunakan } \\
\text { orang yang } \\
\text { tidak } \\
\text { berwenang }\end{array}$} & \multirow{2}{*}{$\begin{array}{c}\text { Akses } \\
\text { menggu } \\
\text { nakan } \\
\text { kompute } \\
\text { r umum } \\
\text { yang } \\
\text { dipasang } \\
\text { aplikasi } \\
\text { spy }\end{array}$} & \multirow[t]{2}{*}{$\begin{array}{l}\text { Keboc } \\
\text { oran } \\
\text { infor } \\
\text { masi }\end{array}$} & & & & & & \\
\hline & & & & & & R3.2 & & $\begin{array}{l}\text { Kesadaran } \\
\text { keamanan } \\
\text { yang }\end{array}$ & $\begin{array}{c}\text { Server } \\
\text { down }\end{array}$ & $\begin{array}{c}\text { Data } \\
\text { pada } \\
\text { server di }\end{array}$ & $\begin{array}{l}\text { Serv } \\
\text { er } \\
\text { dow }\end{array}$ \\
\hline \multirow[t]{2}{*}{$\mathrm{R} 1.2$} & & \multirow[t]{2}{*}{$\begin{array}{c}\text { Ancaman } \\
\text { orang } \\
\text { dalam }\end{array}$} & \multirow[t]{2}{*}{$\begin{array}{c}\text { Data } \\
\text { berubah }\end{array}$} & \multirow{2}{*}{$\begin{array}{l}\text { Menguba } \\
\text { h data } \\
\text { langsung } \\
\text { ke } \\
\text { sistem } \\
\text { aplikasi } \\
\text { Siakad } \\
\end{array}$} & \multirow[t]{2}{*}{$\begin{array}{l}\text { Data } \\
\text { tidak } \\
\text { valid }\end{array}$} & & & kurang. & & $\begin{array}{c}\text { ketahui } \\
\text { orang } \\
\text { yang } \\
\text { tidak } \\
\text { berwena } \\
\text { ng }\end{array}$ & \\
\hline & & & & & & R3.3 & & Terlalu & Server & Listrik & Serve \\
\hline \multirow[t]{2}{*}{ R.1.3 } & & \multirow[t]{2}{*}{$\begin{array}{l}\text { Ancaman } \\
\text { orang } \\
\text { dalam }\end{array}$} & \multirow[t]{2}{*}{$\begin{array}{c}\text { Data hilang } \\
\text { atau tidak } \\
\text { tersedia }\end{array}$} & \multirow{2}{*}{$\begin{array}{c}\text { Kesalaha } \\
\text { n setting } \\
\text { periode } \\
\text { atau } \\
\text { tahun } \\
\text { ajaran } \\
\text { pada } \\
\text { aplikasi } \\
\text { Siakad }\end{array}$} & \multirow{2}{*}{$\begin{array}{c}\text { Data } \\
\text { hilang } \\
\text { atau } \\
\text { terha } \\
\text { pus }\end{array}$} & & & panas & $\begin{array}{c}\text { panas atau } \\
\text { rusak }\end{array}$ & $\begin{array}{l}\text { tidak } \\
\text { stabil }\end{array}$ & $\begin{array}{c}\mathrm{r} \\
\text { panas } \\
\text { atau } \\
\text { rusak }\end{array}$ \\
\hline & & & & & & R3.4 & & $\begin{array}{l}\text { Serangan } \\
\text { pemblokir } \\
\text { an access } \\
\text { point }\end{array}$ & $\begin{array}{c}\text { Koneksi } \\
\text { internet } \\
\text { putus. }\end{array}$ & $\begin{array}{l}\text { Seranga } \\
\mathrm{n} \\
\text { pemblok } \\
\text { iran } \\
\text { access }\end{array}$ & $\begin{array}{l}\text { konek } \\
\text { si } \\
\text { intern } \\
\text { et } \\
\text { putus }\end{array}$ \\
\hline \multirow[t]{3}{*}{$\mathrm{R} 2.1$} & \multirow{3}{*}{$\begin{array}{l}\text { Siste } \\
\mathrm{m}\end{array}$} & \multirow{3}{*}{$\begin{array}{l}\text { Serangan } \\
\text { DDoS, } \\
\text { malware } \\
\text { atau kode } \\
\text { berbahaya }\end{array}$} & \multirow{3}{*}{$\begin{array}{c}\text { Akses } \\
\text { sistem } \\
\text { lambat } \\
\text { atau tidak } \\
\text { tersedia }\end{array}$} & \multirow{3}{*}{$\begin{array}{c}\text { Seranga } \\
\mathrm{n} \text { DDoS, } \\
\text { malware } \\
\text { atau } \\
\text { kode } \\
\text { berbaha } \\
\text { ya } \\
\text { (hacker) }\end{array}$} & \multirow{3}{*}{$\begin{array}{l}\text { Akses } \\
\text { layan } \\
\text { an } \\
\text { siste } \\
\text { m } \\
\text { lamba } \\
\text { t atau } \\
\text { tidak } \\
\text { terse } \\
\text { dia }\end{array}$} & & & & & $\begin{array}{c}\text { point } \\
\text { (hacker) }\end{array}$ & \\
\hline & & & & & & R3.5 & & $\begin{array}{l}\text { Serangan } \\
\text { duplikasi } \\
\text { alamat IP }\end{array}$ & $\begin{array}{c}\text { Sistem } \\
\text { crash atau } \\
\text { error }\end{array}$ & $\begin{array}{l}\text { Seranga } \\
\mathrm{n} \\
\text { duplikasi } \\
\text { alamat } \\
\text { IP } \\
\text { (hacker) }\end{array}$ & $\begin{array}{l}\text { Siste } \\
\mathrm{m} \\
\text { crash } \\
\text { atau } \\
\text { error }\end{array}$ \\
\hline & & & & & & R4.1 & $\begin{array}{l}\text { Serv } \\
\text { er }\end{array}$ & $\begin{array}{l}\text { kerentana } \\
\mathrm{n} \text { terhadap }\end{array}$ & $\begin{array}{c}\text { Sistem } \\
\text { error data }\end{array}$ & $\begin{array}{c}\text { Speck } \\
\text { perangk }\end{array}$ & $\begin{array}{l}\text { Sist } \\
\text { em }\end{array}$ \\
\hline $\mathrm{R} 2.2$ & & $\begin{array}{l}\text { Serangan } \\
\text { deface }\end{array}$ & $\begin{array}{c}\text { Tampilan } \\
\text { halaman } \\
\text { utama web } \\
\text { berubah }\end{array}$ & $\begin{array}{l}\text { Seranga } \\
\text { n deface } \\
\text { (hacker) }\end{array}$ & $\begin{array}{c}\text { Tamp } \\
\text { ilan } \\
\text { halam } \\
\text { an } \\
\text { utam } \\
\text { a web } \\
\text { berub } \\
\text { ah } \\
\end{array}$ & & $\begin{array}{l}\text { Data } \\
\text { base }\end{array}$ & $\begin{array}{l}\text { penyimpan } \\
\text { an yang } \\
\text { tidak } \\
\text { dilindungi }\end{array}$ & $\begin{array}{c}\text { terhapus } \\
\text { atau tidak } \\
\text { bisa } \\
\text { disimpan }\end{array}$ & $\begin{array}{c}\text { at } \\
\text { memori } \\
\text { CPU, } \\
\text { kompute } \\
\text { r tidak } \\
\text { memenu } \\
\text { hi } \\
\text { layanan }\end{array}$ & $\begin{array}{l}\text { erro } \\
r \\
\text { data } \\
\text { terh } \\
\text { apu } \\
\mathrm{s} \\
\text { atau } \\
\text { tida }\end{array}$ \\
\hline \multirow[t]{3}{*}{$\mathrm{R} 2.3$} & & $\begin{array}{l}\text { Kesadaran } \\
\text { keamanan } \\
\text { yang }\end{array}$ & $\begin{array}{l}\text { Data login } \\
\text { diketahui } \\
\text { orang yang }\end{array}$ & $\begin{array}{c}\text { Akses } \\
\text { menggu } \\
\text { nakan }\end{array}$ & $\begin{array}{l}\text { Keboc } \\
\text { oran } \\
\text { infor } \\
\text { masi }\end{array}$ & & & & & & $\begin{array}{l}\mathrm{k} \\
\text { bisa } \\
\text { disim } \\
\text { pan }\end{array}$ \\
\hline & & & $\begin{array}{l}\text { berwenang } \\
\text { dan } \\
\text { penyalahgu } \\
\text { naan data }\end{array}$ & $\begin{array}{l}\text { Kompute } \\
\text { r umum } \\
\text { yang } \\
\text { dipasang } \\
\text { spy atau } \\
\text { sharing }\end{array}$ & masi & $\mathrm{R} 4.2$ & & $\begin{array}{c}\text { Terlalu } \\
\text { panas }\end{array}$ & $\begin{array}{c}\text { Server } \\
\text { panas atau } \\
\text { rusak }\end{array}$ & $\begin{array}{c}\text { Listrik } \\
\text { tidak } \\
\text { stabil }\end{array}$ & $\begin{array}{c}\text { Serve } \\
\mathrm{r} \\
\text { panas } \\
\text { atau } \\
\text { rusak }\end{array}$ \\
\hline & & & & $\begin{array}{l}\text { sharing } \\
\text { email } \\
\text { dan } \\
\text { passwor } \\
d \\
\text { Akses }\end{array}$ & & $\mathrm{R} 4.3$ & & $\begin{array}{c}\text { Ancaman } \\
\text { orang } \\
\text { dalam }\end{array}$ & $\begin{array}{c}\text { Akses } \\
\text { jaringan } \\
\text { terputus }\end{array}$ & $\begin{array}{c}\text { Masalah } \\
\text { konfigur } \\
\text { asi fisik } \\
\text { kabel } \\
\text { lepas } \\
\end{array}$ & $\begin{array}{c}\text { Akses } \\
\text { jaring } \\
\text { an } \\
\text { terput } \\
\text { us } \\
\end{array}$ \\
\hline K2.4 & & $\begin{array}{c}\text { Kesadaran } \\
\text { keamanan } \\
\text { yang } \\
\text { kurang }\end{array}$ & $\begin{array}{l}\text { Perubahan } \\
\text { data LIRS, } \\
\text { login dll }\end{array}$ & $\begin{array}{l}\text { Akses } \\
\text { menggu } \\
\text { nakan } \\
\text { kompute } \\
\text { r umum } \\
\text { yang } \\
\text { dipasang } \\
\text { spy atau } \\
\text { sharing } \\
\text { email }\end{array}$ & $\begin{array}{c}\text { Perub } \\
\text { ahan } \\
\text { data } \\
\text { Siaka } \\
\text { d } \\
\text { (LIRS, } \\
\text { login } \\
\text { dll). }\end{array}$ & R5.1 & $\begin{array}{c}\text { Pera } \\
\text { ngka } \\
t \\
\text { jarin } \\
\text { gan }\end{array}$ & $\begin{array}{c}\text { Ancaman } \\
\text { orang } \\
\text { dalam dan } \\
\text { luar }\end{array}$ & $\begin{array}{c}\text { Akses } \\
\text { koneksi } \\
\text { internet } \\
\text { terputus }\end{array}$ & $\begin{array}{c}\text { Human } \\
\text { error } \\
\text { kabel } \\
\text { tersentu } \\
\text { h atau } \\
\text { ditarik } \\
\text { saat } \\
\text { beraktivi } \\
\text { tas } \\
\end{array}$ & $\begin{array}{l}\text { Akses } \\
\text { konek } \\
\text { si } \\
\text { intern } \\
\text { et } \\
\text { terput } \\
\text { us }\end{array}$ \\
\hline
\end{tabular}




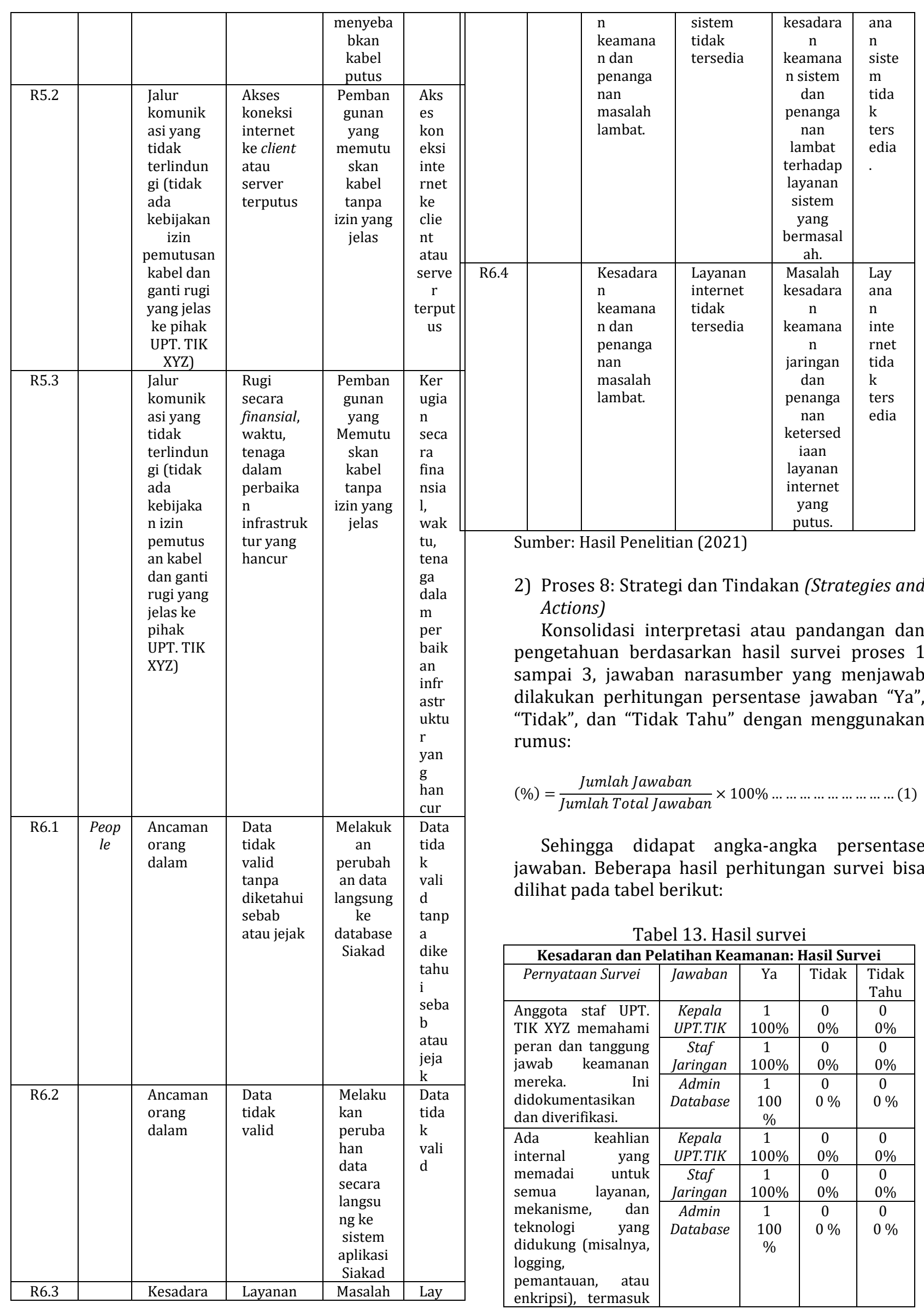




\begin{tabular}{|l|c|c|c|c|}
\hline $\begin{array}{l}\text { keamanan } \\
\text { pengoperasian. Ini } \\
\text { didokumentasikan } \\
\text { dan diverifikasi. }\end{array}$ & & & & \\
\hline Kesadaran akan & & & & \\
keamanan, & & & & \\
pelatihan, dan & UPT.TIK & $100 \%$ & $0 \%$ & 0 \\
\cline { 2 - 5 } pengingat berkala & Staf & 1 & 0 & 0 \\
disediakan untuk & Admin & $100 \%$ & $0 \%$ & $0 \%$ \\
semua personel. & Database & 100 & 0 & 0 \\
$\begin{array}{l}\text { Pemahaman staf } \\
\text { didokumentasikan } \\
\text { dan kesesuaian }\end{array}$ & & $\%$ & $0 \%$ \\
diverifikasi secara \\
berkala.
\end{tabular}

Sumber: Hasil Penelitian (2021)

Selanjutnya dilakukan penilaian risiko menggunakan metode FMEA, dengan pemberian skor Severity (S), Occurrence (O) dan detection (D) sesuai standar FMEA yang sudah ditetapkan tim analisis dan perhitungan RPN dengan rumus:

$$
R P N=(S) \times(O) \times(D)
$$

Hasil perhitungan RPN risiko dapat dilihat pada tabel berikut:

Tabel 14. Tabel Pengkategorian RPN

\begin{tabular}{|c|c|c|c|c|}
\hline Kode & Risiko & Penyebab & RPN & $\begin{array}{c}\text { Kateg } \\
\text { ori }\end{array}$ \\
\hline R6.3 & $\begin{array}{l}\text { Layanan } \\
\text { sistem tidak } \\
\text { tersedia }\end{array}$ & $\begin{array}{c}\text { Masalah } \\
\text { kesadaran } \\
\text { keamanan sistem } \\
\text { dan penanganan } \\
\text { lambat terhadap } \\
\text { layanan sistem } \\
\text { yang bermasalah. }\end{array}$ & 280 & $\begin{array}{l}\text { Very } \\
\text { High }\end{array}$ \\
\hline R6.4 & $\begin{array}{l}\text { Layanan } \\
\text { internet } \\
\text { tidak } \\
\text { tersedia }\end{array}$ & $\begin{array}{c}\text { Masalah } \\
\text { kesadaran } \\
\text { keamanan } \\
\text { jaringan dan } \\
\text { penanganan } \\
\text { ketersediaan } \\
\text { layanan internet } \\
\text { yang putus. }\end{array}$ & 280 & $\begin{array}{l}\text { Very } \\
\text { High }\end{array}$ \\
\hline $\mathrm{R} 5.2$ & $\begin{array}{c}\text { Akses } \\
\text { koneksi } \\
\text { internet ke } \\
\text { client atau } \\
\text { server } \\
\text { terputus } \\
\end{array}$ & $\begin{array}{l}\text { Pembangunan } \\
\text { yang } \\
\text { memutuskan } \\
\text { kabel tanpa izin } \\
\text { yang jelas }\end{array}$ & 140 & $\begin{array}{l}\text { Medi } \\
\text { um }\end{array}$ \\
\hline $\mathrm{R} 5.3$ & $\begin{array}{l}\text { Rugi secara } \\
\text { finansial, } \\
\text { waktu, } \\
\text { tenaga } \\
\text { dalam } \\
\text { perbaikan } \\
\text { infrastruktu } \\
\text { r yang } \\
\text { hancur }\end{array}$ & $\begin{array}{l}\text { Pembangunan } \\
\text { yang } \\
\text { Memutuskan } \\
\text { kabel tanpa izin } \\
\text { yang jelas }\end{array}$ & 140 & $\begin{array}{l}\text { Medi } \\
\text { um }\end{array}$ \\
\hline R6.1 & $\begin{array}{c}\text { Data tidak } \\
\text { valid tanpa } \\
\text { diketahui } \\
\text { sebab atau } \\
\text { jejak } \\
\end{array}$ & $\begin{array}{c}\text { Melakukan } \\
\text { perubahan data } \\
\text { langsung ke } \\
\text { database Siakad }\end{array}$ & 100 & $\begin{array}{l}\text { Medi } \\
\text { um }\end{array}$ \\
\hline $\mathrm{R} 1.2$ & $\begin{array}{c}\text { Data } \\
\text { berubah }\end{array}$ & $\begin{array}{l}\text { Mengubah data } \\
\text { langsung ke } \\
\text { sistem aplikasi }\end{array}$ & 70 & Low \\
\hline
\end{tabular}

\begin{tabular}{|c|c|c|c|c|}
\hline & & Siakad & & \\
\hline R6.2 & $\begin{array}{l}\text { Data tidak } \\
\text { valid }\end{array}$ & $\begin{array}{c}\text { Melakukan } \\
\text { perubahan data } \\
\text { secara langsung } \\
\text { ke sistem } \\
\text { aplikasi Siakad } \\
\end{array}$ & 70 & Low \\
\hline $\mathrm{R} 2.1$ & $\begin{array}{c}\text { Akses sistem } \\
\text { lambat atau } \\
\text { tidak } \\
\text { tersedia } \\
\end{array}$ & $\begin{array}{l}\text { Serangan DDoS, } \\
\text { malware atau } \\
\text { kode berbahaya } \\
\text { (hacker) }\end{array}$ & 60 & Low \\
\hline $\mathrm{R} 2.2$ & $\begin{array}{c}\text { Tampilan } \\
\text { halaman } \\
\text { utama web } \\
\text { berubah }\end{array}$ & $\begin{array}{l}\text { Serangan deface } \\
\text { (hacker) }\end{array}$ & 48 & Low \\
\hline $\mathrm{R} 2.3$ & $\begin{array}{c}\text { Data login } \\
\text { diketahui } \\
\text { orang yang } \\
\text { tidak } \\
\text { berwenang } \\
\text { dan } \\
\text { penyalahgun } \\
\text { aan data } \\
\end{array}$ & $\begin{array}{c}\text { Akses } \\
\text { menggunakan } \\
\text { komputer umum } \\
\text { yang dipasang } \\
\text { spy atau sharing } \\
\text { email dan } \\
\text { password }\end{array}$ & 40 & Low \\
\hline $\mathrm{R} 2.4$ & $\begin{array}{l}\text { Perubahan } \\
\text { data LIRS, } \\
\text { login dll }\end{array}$ & $\begin{array}{c}\text { Akses } \\
\text { menggunakan } \\
\text { komputer umum } \\
\text { yang dipasang } \\
\text { spy atau sharing } \\
\text { email dan } \\
\text { password } \\
\end{array}$ & 40 & Low \\
\hline $\mathrm{R} 4.1$ & $\begin{array}{c}\text { Sistem error } \\
\text { data } \\
\text { terhapus } \\
\text { atau tidak } \\
\text { bisa } \\
\text { disimpan } \\
\end{array}$ & $\begin{array}{l}\text { Speck perangkat } \\
\text { memori CPU, } \\
\text { komputer tidak } \\
\text { memenuhi } \\
\text { layanan }\end{array}$ & 36 & Low \\
\hline R5.1 & $\begin{array}{c}\text { Akses } \\
\text { koneksi } \\
\text { internet } \\
\text { terputus }\end{array}$ & $\begin{array}{c}\text { Human error } \\
\text { kabel tersentuh } \\
\text { atau ditarik saat } \\
\text { beraktivitas } \\
\text { menyebabkan } \\
\text { kabel putus } \\
\text { (Inside dan } \\
\text { outside) }\end{array}$ & 30 & Low \\
\hline $\mathrm{R} 4.3$ & $\begin{array}{c}\text { Akses } \\
\text { jaringan } \\
\text { terputus }\end{array}$ & $\begin{array}{c}\text { Masalah } \\
\text { konfigurasi fisik } \\
\text { kabel lepas }\end{array}$ & 18 & $\begin{array}{l}\text { Very } \\
\text { Low }\end{array}$ \\
\hline $\mathrm{R} 1.3$ & $\begin{array}{l}\text { Data hilang } \\
\text { atau tidak } \\
\text { tersedia }\end{array}$ & $\begin{array}{c}\text { Kesalahan } \\
\text { setting periode } \\
\text { atau tahun ajaran } \\
\text { pada aplikasi } \\
\text { Siakad }\end{array}$ & 14 & $\begin{array}{l}\text { Very } \\
\text { Low }\end{array}$ \\
\hline R1.1 & $\begin{array}{l}\text { Data dibobol } \\
\text { dan di salah } \\
\text { gunakan } \\
\text { orang yang } \\
\text { tidak } \\
\text { berwenang } \\
\end{array}$ & $\begin{array}{c}\text { Akses } \\
\text { menggunakan } \\
\text { komputer umum } \\
\text { yang dipasang } \\
\text { aplikasi spy }\end{array}$ & 10 & $\begin{array}{l}\text { Very } \\
\text { Low }\end{array}$ \\
\hline R3.1 & $\begin{array}{c}\text { Perubahan } \\
\text { setting } \\
\text { server }\end{array}$ & $\begin{array}{c}\text { Data pada server } \\
\text { di ketahui orang } \\
\text { yang tidak } \\
\text { berwenang } \\
\end{array}$ & 10 & $\begin{array}{l}\text { Very } \\
\text { Low }\end{array}$ \\
\hline R3.2 & Server down & $\begin{array}{c}\text { Data pada server } \\
\text { di ketahui orang } \\
\text { yang tidak } \\
\text { berwenang }\end{array}$ & 10 & $\begin{array}{l}\text { Very } \\
\text { Low }\end{array}$ \\
\hline R3.4 & $\begin{array}{l}\text { Koneksi } \\
\text { internet } \\
\text { putus }\end{array}$ & $\begin{array}{l}\text { Serangan } \\
\text { pemblokiran } \\
\text { access point } \\
\text { (hacker) }\end{array}$ & 10 & $\begin{array}{l}\text { Very } \\
\text { Low }\end{array}$ \\
\hline R3.3 & $\begin{array}{c}\text { Server } \\
\text { panas atau } \\
\text { rusak }\end{array}$ & $\begin{array}{l}\text { Listrik tidak } \\
\text { stabil }\end{array}$ & 7 & $\begin{array}{l}\text { Very } \\
\text { Low }\end{array}$ \\
\hline
\end{tabular}

Analisis, Evaluasi, dan Mitigasi Risiko.... 


\begin{tabular}{|c|c|c|c|c|}
\hline R4.2 & $\begin{array}{c}\text { Server } \\
\text { panas atau } \\
\text { rusak }\end{array}$ & $\begin{array}{c}\text { Listrik tidak } \\
\text { stabil }\end{array}$ & 7 & $\begin{array}{c}\text { Very } \\
\text { Low }\end{array}$ \\
\hline R3.5 & $\begin{array}{c}\text { Sistem crash } \\
\text { atau error }\end{array}$ & $\begin{array}{c}\text { Serangan } \\
\text { duplikasi alamat } \\
\text { IP (hacker) }\end{array}$ & 1 & $\begin{array}{c}\text { Very } \\
\text { Low }\end{array}$ \\
\hline
\end{tabular}

Sumber: Hasil Penelitian (2021)

Tabel 15. Jumlah Penilaian Risiko

\begin{tabular}{|c|c|}
\hline Level RPN & Jumlah \\
\hline Very High & 2 Risiko \\
\hline High & 0 Risiko \\
\hline Medium & 3 Risiko \\
\hline Low & 8 Risiko \\
\hline Very Low & 9 Risiko \\
\hline
\end{tabular}

Sumber: Hasil Penelitian (2021)

Dari hasil pengkategorian level RPN diatas didapat level RPN dan jumlah risiko, kemudian RPN risiko diklasifikasikan dengan grafik batang pada bagan pareto untuk membantu menemukan permasalahan yang terpenting untuk segera diselesaikan nilai RPN bisa dilihat pada gambar berikut:

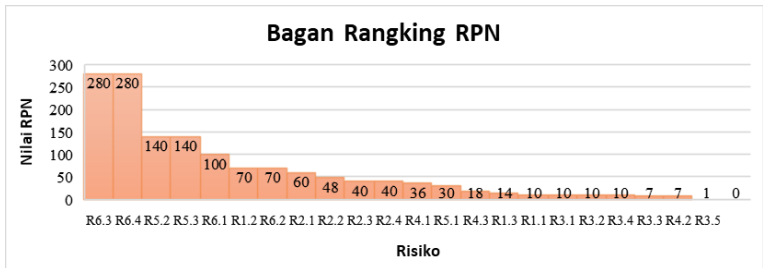

Sumber: Hasil Penelitian (2021)

Gambar 1. Bagan Rangking RPN

Berdasarkan hasil jawaban survei setiap tingkat organisasi yang diubah dalam bentuk angka sebagai indikator preferensi atau kecenderungan dari pilihan responden. Disimpulkan bahwa 75 persen atau lebih responden menjawab "ya" menyatakan bahwa praktik yang digunakan cukup tinggi dan menunjukkan praktik tersebut yang paling kemungkinan digunakan. Responden menjawab "Tidak" 75 persen atau lebih menyatakan bahwa suatu praktik tidak digunakan cukup tinggi dan menunjukkan bahwa praktik tersebut kemungkinan besar tidak digunakan. Kemudian "Tidak jelas" menyatakan tidak satu pun dari dua kriteria persentase "ya" dan "tidak" memenuhi ambang batas 75 persen. Artinya tidak jelas apakah praktiknya digunakan atau tidak ini menujukan kemungkinan beberapa orang di UPT.TIK XYZ menggunakan praktik ini sedangkan yang lain tidak. Beberapa hasil kecenderungan praktik keamanan bisa dilihat pada tabel berikut ini:

Tabel 16. Konsolidasi Hasil Survei Kesadaran dan Pelatihan Keamanan: Hasil Survei

\begin{tabular}{|c|c|c|c|}
\hline Pernyataan Survei & $\begin{array}{l}\text { Kepala } \\
\text { UPT.TIK }\end{array}$ & $\begin{array}{c}\text { Staf } \\
\text { Jaringan }\end{array}$ & $\begin{array}{c}\text { Admin } \\
\text { Database }\end{array}$ \\
\hline $\begin{array}{l}\text { Anggota staf UPT. TIK XYZ } \\
\text { memahami peran dan } \\
\text { tanggung jawab keamanan } \\
\text { mereka. } \\
\text { didokumentasikan } \\
\text { diverifikasi. }\end{array}$ & Ya & Ya & Ya \\
\hline $\begin{array}{l}\text { Ada keahlian internal yang } \\
\text { memadai untuk semua } \\
\text { layanan, mekanisme, dan } \\
\text { teknologi yang didukung } \\
\text { (misalnya, r logging, } \\
\text { pemantauan, } \\
\text { enkripsi), atau } \\
\text { keamanan pengoperasian. } \\
\text { Ini didokumentasikan dan } \\
\text { diverifikasi. }\end{array}$ & Ya & Ya & Ya \\
\hline $\begin{array}{l}\text { Kesadaran akan keamanan, } \\
\text { pelatihan, dan pengingat } \\
\text { berkala disediakan untuk } \\
\text { semua } \\
\text { Pemahaman personel. } \\
\text { didokumentasikan dan } \\
\text { kesesuaian diverifikasi } \\
\text { secara berkala. }\end{array}$ & Ya & Ya & Ya \\
\hline
\end{tabular}

Sumber: Hasil Penelitian (2021)

Selanjutnya berdasarkan hasil dari penanggung jawab aset dan risiko atau ancaman yang ada, didapat respon perlakuan terhadap risiko yang dilakukan dengan wawancara langsung dengan staf pemilik risiko respon risiko dapat dilihat pada tabel berikut ini:

Tabel 17. Jumlah Hasil Respon Risiko

\begin{tabular}{|c|c|c|}
\hline $\begin{array}{l}\text { Ko } \\
\text { de }\end{array}$ & Risiko & Respon Risiko \\
\hline R6.3 & Layanan sistem tidak tersedia & Hindari/Mitigasi \\
\hline R6.4 & $\begin{array}{l}\text { Layanan internet tidak } \\
\text { tersedia }\end{array}$ & Hindari/Mitigasi \\
\hline R5.2 & $\begin{array}{l}\text { Akses koneksi internet ke } \\
\text { client atau server terputus }\end{array}$ & Hindari/Mitigasi \\
\hline R5.3 & $\begin{array}{l}\text { Rugi secara finansial, waktu, } \\
\text { tenaga dalam perbaikan } \\
\text { infrastruktur yang hancur }\end{array}$ & Hindari/Mitigasi \\
\hline R6.1 & $\begin{array}{l}\text { Data tidak valid tanpa } \\
\text { diketahui sebab atau jejak }\end{array}$ & Hindari/Mitigasi \\
\hline $\mathrm{R} 1.2$ & Data berubah & Hindari/Mitigasi \\
\hline R6.2 & Data tidak valid & Hindari/Mitigasi \\
\hline $\mathrm{R} 2.1$ & $\begin{array}{l}\text { Akses sistem lambat atau } \\
\text { tidak tersedia }\end{array}$ & Hindari/Mitigasi \\
\hline $\mathrm{R} 2.2$ & $\begin{array}{l}\text { Tampilan halaman utama } \\
\text { web berubah }\end{array}$ & Hindari/Mitigasi \\
\hline $\mathrm{R} 2.3$ & $\begin{array}{l}\text { Data login diketahui orang } \\
\text { yang tidak berwenang dan } \\
\text { penyalahgunaan data }\end{array}$ & Hindari/Mitigasi \\
\hline $\mathrm{R} 2.4$ & Perubahan data LIRS, login dll & Hindari/Mitigasi \\
\hline $\mathrm{R} 4.1$ & $\begin{array}{l}\text { Sistem error data terhapus } \\
\text { atau tidak bisa disimpan }\end{array}$ & Hindari/Mitigasi \\
\hline R5.1 & $\begin{array}{l}\text { Akses koneksi internet } \\
\text { terputus }\end{array}$ & Hindari/Mitigasi \\
\hline $\mathrm{R} 4.3$ & Akses jaringan terputus & Hindari/Mitigasi \\
\hline R1.3 & $\begin{array}{l}\text { Data hilang atau tidak } \\
\text { tersedia }\end{array}$ & Hindari/Mitigasi \\
\hline R1.1 & $\begin{array}{l}\text { Data dibobol dan di salah } \\
\text { gunakan orang yang tidak } \\
\text { berwenang }\end{array}$ & Hindari/Mitigasi \\
\hline R3.1 & Perubahan setting server & Hindari/Mitigasi \\
\hline
\end{tabular}




\begin{tabular}{|l|l|l|}
\hline R3.2 & Server down & Hindari/Mitigasi \\
\hline R3.4 & Koneksi internet putus & Hindari/Mitigasi \\
\hline R3.3 & $\begin{array}{l}\text { Server panas atau rusak } \\
\text { (jaringan) }\end{array}$ & Berbagi/Mitigasi \\
\hline
\end{tabular}

Sumber: Hasil Penelitian (2021)

Selanjutnya pemilihan praktik strategi dan praktik operasional dan sub kontrol yang disesuaikan dengan hasil jawaban kecenderungan praktik keamanan yang hasilnya "Tidak" yang berarti praktik tidak digunakan cukup tinggi ini menunjukan kemungkinan besar tidak digunakan dan "Tidak Jelas" yang berarti apakah praktiknya digunakan atau tidak ini menujukan kemungkinan beberapa orang di UPT.TIK XYZ menggunakan praktik ini sedangkan yang lain tidak yang berarti praktik di UPT.TIK. Hasilnya ada 10 bidang praktik dengan Pemilihan praktik strategi dan praktik operasional dan sub kontrol nya bisa dilihat tabel sebagai berikut:

Tabel 18. Memilih Praktik Strategis dan Praktik Operasional

\begin{tabular}{|c|c|c|c|c|c|}
\hline \multirow[t]{2}{*}{$\begin{array}{l}\mathbf{N} \\
\mathbf{o .}\end{array}$} & \multirow{2}{*}{$\begin{array}{c}\text { Praktik } \\
\text { Strategi/ } \\
\text { Praktik } \\
\text { Operasional }\end{array}$} & \multirow{2}{*}{$\begin{array}{c}\text { Sub } \\
\text { Praktik } \\
\text { Strategis/ } \\
\text { Praktik } \\
\text { Operasion } \\
\text { al }\end{array}$} & \multicolumn{3}{|c|}{$\begin{array}{c}\text { Hasil } \\
\text { Kecenderungan } \\
\text { Praktik Keamanan } \\
\end{array}$} \\
\hline & & & $\begin{array}{l}\text { Kepa } \\
\text { la } \\
\text { UPT. } \\
\text { TIK }\end{array}$ & $\begin{array}{c}\text { Staf } \\
\text { Jarin } \\
\text { gan }\end{array}$ & $\begin{array}{l}\text { Admi } \\
n \\
\text { Datab } \\
\text { ase }\end{array}$ \\
\hline 1. & $\begin{array}{l}\text { Strategi } \\
\text { Keamanan } \\
(\mathrm{SP} 2)\end{array}$ & $\begin{array}{l}\text { Praktik } \\
\text { strategi } \\
\text { (SP2.3) }\end{array}$ & $\mathrm{Ya}$ & Ya & Tidak \\
\hline \multirow[t]{4}{*}{2.} & \multirow{4}{*}{$\begin{array}{l}\text { Kebijakan } \\
\text { dan } \\
\text { Peraturan } \\
\text { Keamanan } \\
\text { (SP4) }\end{array}$} & $\begin{array}{l}\text { Praktik } \\
\text { strategi } \\
\text { (SP4.1) }\end{array}$ & $\begin{array}{l}\text { Tida } \\
\mathrm{k}\end{array}$ & $\mathrm{Ya}$ & $\begin{array}{l}\text { Tidak } \\
\text { Jelas }\end{array}$ \\
\hline & & $\begin{array}{l}\text { Praktik } \\
\text { strategi } \\
\text { (SP4.2) }\end{array}$ & $\mathrm{Ya}$ & $\mathrm{Ya}$ & $\begin{array}{l}\text { Tidak } \\
\text { Jelas }\end{array}$ \\
\hline & & $\begin{array}{l}\text { Praktik } \\
\text { strategi } \\
\text { (SP4.3) }\end{array}$ & Ya & Ya & $\begin{array}{l}\text { Tidak } \\
\text { Jelas }\end{array}$ \\
\hline & & $\begin{array}{l}\text { Praktik } \\
\text { strategi } \\
\text { (SP4.5) }\end{array}$ & Ya & Ya & $\begin{array}{l}\text { Tidak } \\
\text { Jelas }\end{array}$ \\
\hline 3. & $\begin{array}{l}\text { Manajemen } \\
\text { Keamanan } \\
\text { Kolaboratif } \\
\text { (SP5) }\end{array}$ & $\begin{array}{l}\text { Praktik } \\
\text { strategi } \\
\text { (SP5.1) }\end{array}$ & $\mathrm{Ya}$ & $\begin{array}{l}\text { Tidak } \\
\text { Jelas }\end{array}$ & Ya \\
\hline \multirow[t]{2}{*}{4.} & \multirow{2}{*}{$\begin{array}{l}\text { Perencanaan } \\
\text { Kontingensi } \\
\text { / Pemulihan } \\
\text { Bencana } \\
\text { (SP6) }\end{array}$} & $\begin{array}{l}\text { Praktik } \\
\text { strategi } \\
\text { (SP6.2) }\end{array}$ & Ya & Ya & $\begin{array}{l}\text { Tidak } \\
\text { Jelas }\end{array}$ \\
\hline & & $\begin{array}{l}\text { Praktik } \\
\text { strategi } \\
\text { (SP6.3) }\end{array}$ & Ya & Ya & $\begin{array}{l}\text { Tidak } \\
\text { Jelas }\end{array}$ \\
\hline \multirow[t]{3}{*}{5.} & \multirow{3}{*}{$\begin{array}{l}\text { Keamanan } \\
\text { Fisik (OP1) } \\
\text { Rencana dan } \\
\text { Prosedur } \\
\text { Keamanan } \\
\text { Fisik (OP1.1) }\end{array}$} & $\begin{array}{l}\text { Praktik } \\
\text { operasiona } \\
\text { l (OP1.1.1) }\end{array}$ & $\begin{array}{l}\text { Tida } \\
\mathrm{k}\end{array}$ & $\begin{array}{l}\text { Tida } \\
\mathrm{k} \\
\text { Jelas } \\
\end{array}$ & $\begin{array}{l}\text { Tidak } \\
\text { Jelas }\end{array}$ \\
\hline & & $\begin{array}{l}\text { Praktik } \\
\text { operasiona } \\
\text { l (OP1.1.4) }\end{array}$ & Ya & $\begin{array}{l}\text { Tida } \\
\mathrm{k} \\
\text { Jelas }\end{array}$ & $\begin{array}{l}\text { Tidak } \\
\text { Jelas }\end{array}$ \\
\hline & & $\begin{array}{l}\text { Praktik } \\
\text { operasiona } \\
\text { l (OP1.1.5) } \\
\end{array}$ & Ya & $\begin{array}{l}\text { Tida } \\
\mathrm{k} \\
\text { Jelas } \\
\end{array}$ & $\begin{array}{l}\text { Tidak } \\
\text { Jelas }\end{array}$ \\
\hline 6. & $\begin{array}{l}\text { Keamanan } \\
\text { Fisik (OP1) } \\
\text { Kontrol }\end{array}$ & $\begin{array}{l}\text { Praktik } \\
\text { operasiona } \\
\text { l (OP1.2.2) }\end{array}$ & $\mathrm{Ya}$ & $\begin{array}{l}\text { Tida } \\
\mathrm{k} \\
\text { Jelas }\end{array}$ & $\begin{array}{l}\text { Tidak } \\
\text { Jelas }\end{array}$ \\
\hline
\end{tabular}

\begin{tabular}{|c|c|c|c|c|c|}
\hline & $\begin{array}{l}\text { Akses Fisik } \\
(\mathrm{OP} 1.2)\end{array}$ & $\begin{array}{l}\text { Praktik } \\
\text { operasiona } \\
\text { l (OP1.2.4) }\end{array}$ & Ya & $\begin{array}{l}\text { Tida } \\
\mathrm{k} \\
\text { Jelas }\end{array}$ & Ya \\
\hline 7. & $\begin{array}{l}\text { Keamanan } \\
\text { Fisik (OP1) } \\
\text { Pemantauan } \\
\text { dan Audit } \\
\text { Keamanan } \\
\text { Fisik (OP1.3) }\end{array}$ & $\begin{array}{l}\text { Praktik } \\
\text { operasiona } \\
1 \text { (OP1.3.3) }\end{array}$ & - & $\begin{array}{l}\text { Tida } \\
\mathrm{k} \\
\text { Jelas }\end{array}$ & Ya \\
\hline 8. & $\begin{array}{l}\text { Keamanan } \\
\text { Teknologi } \\
\text { Informasi } \\
(\mathrm{OP} 2) \\
\text { Pemantauan } \\
\text { dan Audit } \\
\text { Keamanan TI } \\
\text { (OP2.3) }\end{array}$ & $\begin{array}{l}\text { Praktik } \\
\text { operasiona } \\
\text { l (OP2.3.1) }\end{array}$ & - & $\begin{array}{l}\text { Tida } \\
\mathrm{k} \\
\text { Jelas }\end{array}$ & $\mathrm{Ya}$ \\
\hline \multirow[t]{2}{*}{9.} & \multirow{2}{*}{$\begin{array}{l}\text { Keamanan } \\
\text { Staf (OP3) } \\
\text { Manajemen } \\
\text { Insiden } \\
\text { (OP3.1) }\end{array}$} & $\begin{array}{l}\text { Praktik } \\
\text { operasiona } \\
1 \text { (OP3.1.2) }\end{array}$ & $\begin{array}{l}\text { Tida } \\
\mathrm{k}\end{array}$ & $\mathrm{Ya}$ & $\mathrm{Ya}$ \\
\hline & & $\begin{array}{l}\text { Praktik } \\
\text { operasiona } \\
1 \text { (OP3.1.3) }\end{array}$ & $\begin{array}{l}\text { Tida } \\
\mathrm{k}\end{array}$ & Ya & $\begin{array}{l}\text { Tidak } \\
\text { Jelas }\end{array}$ \\
\hline 10 & $\begin{array}{l}\text { Keamanan } \\
\text { Staf (OP3) } \\
\text { Praktik Staf } \\
\text { Umum } \\
\text { (OP3.2) }\end{array}$ & $\begin{array}{l}\text { Praktik } \\
\text { operasiona } \\
\text { l (OP3.2.3) }\end{array}$ & $\mathrm{Ya}$ & Ya & $\begin{array}{l}\text { Tidak } \\
\text { Jelas }\end{array}$ \\
\hline
\end{tabular}

Sumber: Hasil Penelitian (2021)

Rencana mitigasi risiko menggunakan standar internasional yaitu ISO/IEC 27001:2013 sebagai standar sistem manajemen keamanan yang disesuaikan berdasarkan risiko di UPT.TIK XYZ dan penyebabnya secara objektif. Penentuan klausul dan kontrol objektif bisa dilihat pada tabel berikut:

Tabel 19. Memilih Klausul dan Kontrol Objektif

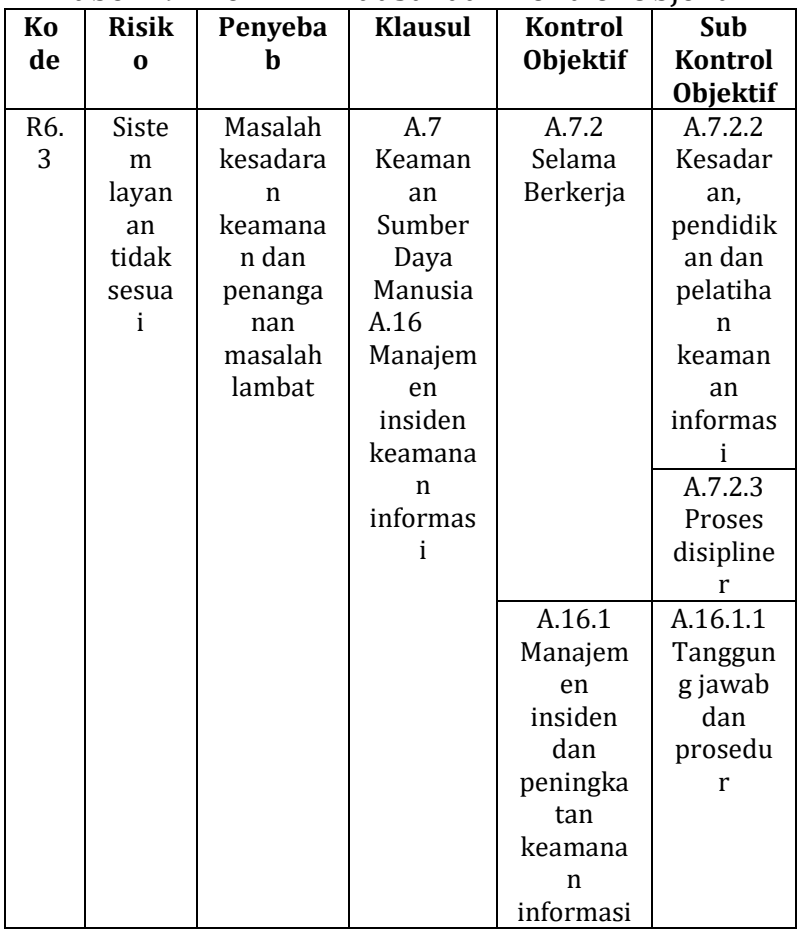

Sumber: Hasil Penelitian (2021) 
Rekomendasi pengembangan praktik yang diberikan terdiri dari dua yaitu praktik strategis dan praktik operasional yang sudah dilakukan dengan menyesuaikan hasil survei sebelumnya. Rekomendasi yang dibuat sesuai dengan standar OCTAVE Katalog Versi 2.0 sebagai rencana mengembangkan strategis yang harus diterapkan beberapa rekomendasi pengembangan praktik UPT.TIK XYZ bisa dilihat pada tabel berikut:

Tabel 20. Pengembangan Praktik

\begin{tabular}{|l|l|}
\hline \multicolumn{3}{|c|}{ Praktik Strategis } \\
\hline SP2.3 & $\begin{array}{l}\text { Strategi, sasaran, dan tujuan keamanan } \\
\text { didokumentasikan dan secara rutin ditinjau, } \\
\text { diperbarui, dan dikomunikasikan kepada } \\
\text { UPT.TIK XYZ. }\end{array}$ \\
\hline
\end{tabular}

Sumber: Hasil Penelitian (2021)

Selanjutnya mitigasi risiko dari pemilihan klausul dan kontrol objektif yang sudah dilakukan sebelumnya berdasarkan ISO/IEC 27001:2013 ditambah dengan rekomendasi implementasi dari klausul dan kontrol objektif berdasarkan ISO/IEC 27002:2013. Dilakukan dengan menyesuaikan penyebab dari masing-masing risiko untuk mengurangi risiko berdasarkan hasil identifikasi dan analisis risiko. Penjelasan mitigasi risiko yang dibuat bisa dilihat tabel berikut ini:

Tabel 21. Pengembangan Praktik

\begin{tabular}{|l|l|}
\hline Kode Risiko & R6.3 \\
\hline Kategori & People (programmer) \\
\hline Risiko & Sistem layanan tidak sesuai \\
\hline Penyebab & $\begin{array}{l}\text { Masalah kesadaran keamanan dan } \\
\text { penanganan masalah lambat }\end{array}$ \\
\hline Kontrol & $\begin{array}{l}\text { A.7.2.2 Kesadaran, pendidikan dan } \\
\text { Objektifihan keamanan informasi } \\
\text { Semua staf programmer dan, jika relevan, } \\
\text { programmer kontrak harus menerima } \\
\text { pendidikan dan pelatihan kesadaran yang } \\
\text { sesuai dan pembaruan rutin dalam } \\
\text { kebijakan dan prosedur UPT.TIK XYZ, yang } \\
\text { relevan dengan fungsi pekerjaan mereka. }\end{array}$ \\
\cline { 2 - 3 } & $\begin{array}{l}\text { A.7.2.3 Proses disipliner } \\
\text { Harus ada proses disipliner formal dan } \\
\text { yang dikomunikasikan kepada } \\
\text { programmer untuk mengambil tindakan } \\
\text { yang telah melakukan pelanggaran } \\
\text { kebijakan yang sudah ditetapkan oleh } \\
\text { UPT.TIK XYZ. }\end{array}$ \\
\cline { 2 - 3 } & $\begin{array}{l}\text { A.16.1.1 Tanggung jawab dan prosedur } \\
\text { Tanggung jawab dan prosedur manajemen } \\
\text { harus ditetapkan pada setiap programmer } \\
\text { untuk memastikan respons yang cepat, } \\
\text { efektif dan teratur terhadap insiden } \\
\text { keamanan informasi atau masalah sistem } \\
\text { layanan yang dilaporkan ke pihak UPT.TIK } \\
\text { XYZ terkait masalah sistem layanan. }\end{array}$ \\
$\begin{array}{l}\text { 1. Menjalankan dan mengembangkan } \\
\text { program pendidikan dan pelatihan } \\
\text { keamanan informasi yang dilakukan } \\
\text { secara berkala untuk meningkatkan } \\
\text { kepedulian (awareness) programmer. } \\
\text { Adanya proses mendisiplinkan } \\
\text { formal terhadap pelanggaran yang }\end{array}$ \\
\hline Implementasi
\end{tabular}

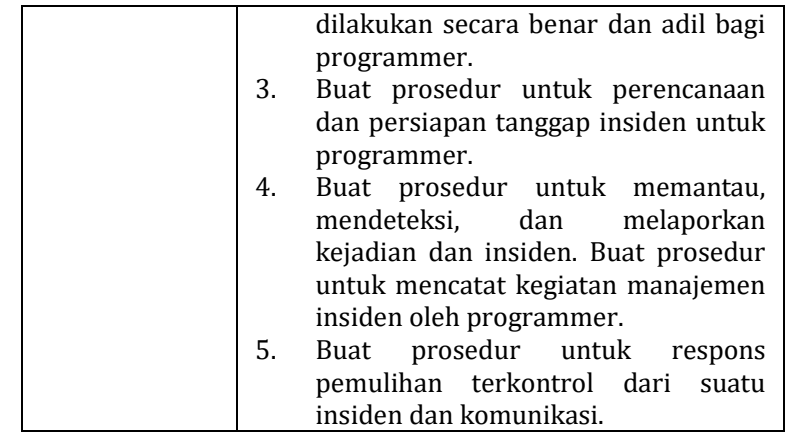

Sumber: Hasil Penelitian (2021)

5. Validasi potensi penerapan rekomendasi praktik keamanan dan mitigasi risiko

Selanjutnya melakukan pengujian atau validasi potensi penerapan dengan memastikan bahwa rekomendasi pengembangan praktik dan mitigasi risiko sesuai dengan kondisi dan harapan UPT.TIK XYZ dapat dilihat pada tabel berikut:

Tabel 22. Pengujian Rekomendasi Pengembangan Praktik

\begin{tabular}{|c|c|c|c|c|}
\hline $\begin{array}{l}\mathbf{N} \\
\mathbf{0}\end{array}$ & $\begin{array}{l}\text { Strategi } \\
\text { Praktik } \\
\text { (SP) / } \\
\text { Strategi } \\
\text { Operasio } \\
\text { nal (OP) }\end{array}$ & $\begin{array}{l}\text { Sub } \\
\text { Strategi } \\
\text { Praktik } \\
\text { (SP) / } \\
\text { Strategi } \\
\text { Operasio } \\
\text { nal (OP) }\end{array}$ & Tujuan & $\begin{array}{l}\text { Potensi } \\
\text { Penerapan }\end{array}$ \\
\hline 1. & $\begin{array}{l}\text { Strategi } \\
\text { Keamana } \\
\text { n (SP2) }\end{array}$ & $\begin{array}{l}\text { Praktik } \\
\text { strategi } \\
\text { (SP2.3) }\end{array}$ & $\begin{array}{l}\text { Strategi, } \\
\text { sasaran, dan } \\
\text { tujuan } \\
\text { keamanan } \\
\text { didokumentas } \\
\text { ikan dan } \\
\text { secara rutin } \\
\text { ditinjau, } \\
\text { diperbarui, } \\
\text { dan } \\
\text { dikomunikasi } \\
\text { kan kepada } \\
\text { Organisasi. }\end{array}$ & $\begin{array}{l}\text { Dapat } \\
\text { diterapkan } \\
\text { UPT. TIK XYZ } \\
\text { dengan } \\
\text { menyusun } \\
\text { praktik } \\
\text { strategi, } \\
\text { sasaran dan } \\
\text { tujuan } \\
\text { keamanan } \\
\text { yang } \\
\text { dilakukan } \\
\text { untuk } \\
\text { dibagikan } \\
\text { dan } \\
\text { dikomunikas } \\
\text { ikan kepada } \\
\text { setiap staf } \\
\text { agar } \\
\text { mengerti. }\end{array}$ \\
\hline
\end{tabular}

Sumber: Hasil Penelitian (2021)

Tabel 23. Pengujian Rekomendasi Mitigasi Risiko

\begin{tabular}{|c|c|c|c|c|c|}
\hline $\begin{array}{l}\mathbf{N} \\
\mathbf{0}\end{array}$ & $\begin{array}{l}\text { Kon } \\
\text { trol } \\
\text { Obje } \\
\text { ktif }\end{array}$ & $\begin{array}{l}\text { Sub } \\
\text { Kontr } \\
\text { ol } \\
\text { Objekt } \\
\text { if }\end{array}$ & Tujuan & $\begin{array}{l}\text { Implem } \\
\text { entasi }\end{array}$ & $\begin{array}{l}\text { Potensi } \\
\text { Penerap } \\
\text { an }\end{array}$ \\
\hline 1 & $\begin{array}{l}\text { A.5.1 } \\
\text { Arah } \\
\text { an } \\
\text { man } \\
\text { ajem } \\
\text { en } \\
\text { untu } \\
\text { k } \\
\text { kea }\end{array}$ & A.5.1.1 & $\begin{array}{l}\text { Serangkaian } \\
\text { kebijakan } \\
\text { untuk } \\
\text { keamanan } \\
\text { informasi } \\
\text { terkait } \\
\text { perizinan } \\
\text { pembanguna } \\
\text { n yang }\end{array}$ & $\begin{array}{l}\text { Membua } \\
\mathrm{t} \\
\text { kebijaka } \\
\mathrm{n} \\
\text { strategi } \\
\text { bisnis, } \\
\text { peratura } \\
\mathrm{n}, \\
\text { perunda }\end{array}$ & $\begin{array}{l}\text { Dapat } \\
\text { diterapk } \\
\text { an UPT. } \\
\text { TIK } \\
\text { dengan } \\
\text { menyusu } \\
\text { n } \\
\text { dokume } \\
\text { n terkait }\end{array}$ \\
\hline
\end{tabular}




\begin{tabular}{|c|c|c|c|}
\hline $\begin{array}{l}\text { man } \\
\text { an } \\
\text { infor } \\
\text { masi }\end{array}$ & $\begin{array}{l}\text { melibatkan } \\
\text { aset XYZ, } \\
\text { ganti rugi } \\
\text { yang } \\
\text { melibatkan } \\
\text { kerusakan } \\
\text { infrastruktur } \\
\text { jaringan } \\
\text { internet XYZ } \\
\text { dan data } \\
\text { nilai harus } \\
\text { ditetapkan, } \\
\text { disetujui } \\
\text { oleh } \\
\text { manajemen, } \\
\text { dipublikasik } \\
\text { an dan } \\
\text { dikomunikas } \\
\text { ikan kepada } \\
\text { staf UPT.TIK } \\
\text { XYZ dan } \\
\text { pihak } \\
\text { eksternal } \\
\text { terkait. }\end{array}$ & $\begin{array}{l}\text { ng- } \\
\text { undanga } \\
\mathrm{n} \quad \text { dan } \\
\text { kontrak, } \\
\text { lingkung } \\
\text { an } \\
\text { ancaman } \\
\text { yang } \\
\text { mendefi } \\
\text { nisikan } \\
\text { keamana } \\
\mathrm{n} \\
\text { informas } \\
\mathrm{i} \text {, tujuan } \\
\text { dan } \\
\text { prinsip } \\
\text { yang } \\
\text { memand } \\
\text { u } \\
\text { kegiatan } \\
\text { yang } \\
\text { berkaita } \\
\text { n dengan } \\
\text { keamana } \\
\text { n aset } \\
\text { terkait } \\
\text { pemban } \\
\text { gunan }\end{array}$ & $\begin{array}{l}\text { kebijaka } \\
\text { n terkait } \\
\text { strategi } \\
\text { bisnis } \\
\text { dan } \\
\text { kebijaka } \\
\mathrm{n} \text { untuk } \\
\text { keamana } \\
\mathrm{n} \\
\text { informas } \\
\mathrm{i} \text { dan } \\
\text { aset } \\
\text { terkait } \\
\text { pembang } \\
\text { unan } \\
\text { yang } \\
\text { melibatk } \\
\text { an aset } \\
\text { XYZ, } \\
\text { ganti } \\
\text { rugi dll. }\end{array}$ \\
\hline
\end{tabular}

Sumber: Hasil Penelitian (2021)

\section{KESIMPULAN}

Kesimpulan dari penelitian ini yang sudah dilakukan identifikasi aset kritis diperoleh 19 risiko dan 22 kejadian ancaman dengan demikian terdapat risiko yang memiliki kejadian ancaman lebih dari satu karena memiliki lebih dari satu dampak. Kemudian dari proses identifikasi pengetahuan juga dilakukan survei terkait praktik yang digunakan di UPT.TIK XYZ menggunakan standar OCTAVE yang dilakukan dengan beberapa perwakilan diperoleh 10 praktik keamanan yang memiliki jawaban hasil "Tidak" dan/atau "Tidak Jelas". "Tidak" yang berarti praktik tidak digunakan cukup tinggi ini menunjukan kemungkinan besar tidak digunakan dan "Tidak Jelas" yang berarti apakah praktiknya digunakan atau tidak ini menujukan kemungkinan beberapa orang di UPT.TIK XYZ menggunakan praktik ini sedangkan yang lain tidak yang berarti praktik di UPT.TIK.

Selanjutnya dari hasil penilaian RPN menggunakan FMEA dikategorikan ke empat level penilaian risiko very high memiliki 2 risiko dengan nilai RPN sebesar 280, high memiliki 0 risiko, medium memiliki 3 risiko dengan nilai RPN sebesar 100-140, low memiliki 8 risiko dengan nilai RPN sebesar 30-70 dan very low memiliki 9 risiko dengan nilai RPN sebesar 1-18.

Kemudian dari hasil survei praktik terdapat 10 praktik strategi (SP) atau praktik operasional (OP) dalam OCTAVE Katalog Versi 2.0 yang dijadikan acuan standar. Rekomendasi Pengembangan Praktik atau praktik yang harus dikembangkan di
UPT.TIK XYZ seperti strategi keamanan (SP2), kebijakan dan peraturan keamanan (SP4), manajemen keamanan kolaboratif (SP5), perencanaan kontingensi atau pemulihan bencana (SP6), rencana dan prosedur keamanan fisik (OP1.1), kontrol akses fisik (OP1.2), pemantauan dan audit keamanan fisik (OP1.3), pemantauan dan audit keamanan TI (OP2.3), manajemen insiden (OP3.1), dan praktik staf umum (OP3.2).

Dari hasil identifikasi risiko terdapat 10 kontrol dan 26 klausul dalam ISO 27001:2013 dan ISO 27002:2013 yang dijadikan acuan standar rekomendasi mitigasi risiko dan implementasi seperti A.5 kebijakan keamanan informasi, A.6 organisasi keamanan informasi, A.7 keamanan sumber daya manusia, A.9 akses kontrol, A.10 kriptografi, A.11 keamanan fisik dan lingkungan, A.12 keamanan operasi, A.13 keamanan komunikasi, A.15 hubungan pemasok, dan A.16 manajemen insiden keamanan informasi.

\section{REFERENSI}

AIAG-VDA Failur Mode And Effects Analysis (FMEA) Handbook First Edition. (2017). Southfield: AIAG.

Carlson, C. S. (2014). Understanding and Applying the Fundamentals of FMEAs. Tucson: AR\&MS Tutorial Notes.

FMEA Handbook Version 4.2. (2011). Dearborn: Ford Motor Company.

FMEA HANDBOOK VERSION 4.2. (2011). DEARBORN: Ford Motor Company.

ISO/IEC 27001 Information Technology Security Techniques Information Security Management System Requirements. (2013). Switzerland: ISO/IEC 2013.

ISO/IEC 27002 Information technology Security techniques Code of practice for information security. (2013). Switzerland: ISO/IEC 2013.

Putri, A. H., \& Kusumawati, Y. (2017). Strategi Mitigasi Risiko Aset Kritis Teknologi Informasi . Techno.COM, Vol. 16, No. 4, November 2017 : 367-3777.

Stebbins, E. J., \& Turgeon, A. (2018). Guide to Risk Assement and Response. Wheelock : The University of Vermont.

Vacca, J. R. (2017). Computer and Information Security Handbook Third Edition. Cambridge: Morgan Kaufmann. 